\title{
Relating 3D surface displacement from satellite- and ground-based InSAR to structures and geomorphology of the Jettan rockslide, northern Norway
}

\author{
Harald Øverli Eriksen 1,2, Steffen G. Bergh², Yngvar Larsen', Ingrid Skrede ${ }^{3}$, \\ Lene Kristensen ${ }^{3}$, Tom Rune Lauknes', Lars Harald Blikra ${ }^{2,3}$ \& Halfdan Pascal Kierulf ${ }^{4}$ \\ ${ }^{1}$ Norut, P.O. Box 6434, N-9294 Tromsø, Norway. \\ ${ }^{2}$ Department of Geosciences, UiT - The Arctic University of Norway, P.O. Box 6050 Langnes, N-9037 Tromsø, Norway. \\ ${ }^{3}$ Norwegian Water Resources and Energy Directorate, Vestre Rosten 81, N-7075 Tiller, Norway. \\ ${ }^{4}$ Norwegian Mapping Authority, P.O. Box 600 Sentrum, N-3507 Hønefoss, Norway. \\ E-mail corresponding author (Harald Øverli Eriksen): haraldoverlieriksen@gmail.com
}

\begin{abstract}
This study combines remote sensing data from ground- and satellite-based radar to calculate $3 \mathrm{D}$ displacement vectors for the Jettan rockslide, Troms, northern Norway. Using 3D displacement vectors, aspect data and strain rates in conjunction with structure (foliation, faults, fractures), geomorphological elements (ridges, scarps, terraces, depressions), topography and borehole data, we identify zones undergoing displacement, e.g., extension and compression, displacement into- or out-of-the-slope and/or various degrees of tilting. Our results show variable 3D displacement velocities, from north to south, that segment the rockslide into distinct domains. Displacement patterns are structurally controlled, as spatial variation in azimuth and plunge of 3D displacement vectors can be related to variation in attitudes of the host-rock foliation, faults and fractures. In the north, a complex graben system surrounded by orthogonal NW-SE and NE-SW-trending geomorphological elements, shows a repeated stepping 3D displacement pattern. This may indicate a complex fault geometry at depth, including stepped and discontinuous slide surfaces. We interpret 3D displacement into-the-slope in the upper part, and out-of-the-slope in the lower part, to be back-rotation of antithetic blocks with planar fractures becoming curved/listric gliding surfaces with depth. Downslope reduction in velocity indicates compression and stacking of blocks. In the southern area, N-S-trending geomorphological elements are arranged parallel to the hillslope. 3D displacement vectors show a more homogenous displacement pattern indicating movement along planar, hillslope-parallel, fracture sets at depth. We propose a structuralcontrolled slope displacement model including alternate planar- and wedge-failure, in addition to displacement along planar and listric fractures merging into foliation at depth. Using the Jettan rockslide as a case study, we show how remote sensing data may aid examination of structural and topographic controls on rockslide kinematics, thus giving new insights into subsurface geometry
\end{abstract}

Keywords: Structural-controlled rock-slope failure, Three-dimensional displacement map, Radar remote sensing, Rockslide kinematics, TerraSAR-X, Monitoring

Received 18. June 2017 / Accepted 1. November 2017 / Published online 13. December 2017

\section{Introduction}

Use of satellite- and ground-based radar for observation and monitoring of ongoing displacement combined with structural and geomorphological studies of complex rockslides is an evolving field. The technique is used in a variety of applications spanning from surveillance of man-made structures and mines (Tarchi et al., 1999; Gourmelen et al., 2007; Pieraccini, 2013), monitoring of displacement patterns in natural processes like earthquakes, glacier flow (Goldstein et al., 1993), volcano deformation (Massonnet et al., 1995) and subsidence (Strozzi et al., 2001; Righini et al., 2011; Chaussard et al., 2014), to unstable rockslide/landslide areas (Berardino et al., 2003; Tarchi et al., 2003; Lauknes et al., 2010).

Eriksen, H.Ø., Bergh. S.G., Larsen, Y., Skrede, I., Kristensen, L., Lauknes, T.R., Blikra, L.H. \& Kierulf, H.P. 2017: Relating 3D surface displacement from satellite- and ground-based InSAR to structures and geomorphology of the Jettan rockslide, northern Norway. Norwegian Journal of Geology 97, 283-303. https://dx.doi.org/10.17850/njg97-4-03. 
Both ground- and satellite-based radar instruments have proven to be reliable tools for measuring displacement in unstable rockslide areas, with main advantages including: (1) large spatial sampling, (2) all-day all-weather capability, and (3) the possibility to observe displacement velocity ranging in scale from $\mathrm{mm} \mathrm{yr}^{-1}$ to $10 \mathrm{~s} \mathrm{~m} \mathrm{yr}^{-1}$. The temporal resolution differs between ground- and satellite-based radar. While a ground-based radar acquires a new scene within minutes, the satellite-based radar has a repeat pass of several days. This difference in temporal resolution makes the ground-based radar capable of observing much higher velocities than the satellite-based radar before decorrelation occurs or unwrapping of interferograms is needed.

Remote sensing using single geometry radar datasets is limited to measuring displacement in the instrument's Line-Of-Sight (LOS) direction, while sensitivity to displacement in other directions is underestimated. If the direction of displacement is orthogonal to the instrument's LOS direction, the displacement will be invisible to the instrument. Several approaches have been proposed for increasing sensitivity by combining overlapping displacement datasets. Techniques for resolving deformation in three dimensions (3D) for earthquakes and glaciers, such as azimuthal offsets (Fialko et al., 2001, 2005) and offset tracking (Nagler et al., 2012), show good results for deformation on the order of decimetres to metres $\mathrm{yr}^{-1}$.

Although studies using both ground- and satellitebased radar separately to observe rockslides having slow velocities have been made (Bardi et al., 2016), studies combining radar datasets to resolve full $3 \mathrm{D}$ displacements are rare due to a low availability of overlapping ground- and satellite-based datasets in time and space.

In this study, we combine ground- and satellite-based radar data to derive $3 \mathrm{D}$ displacement vectors for areas

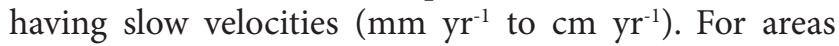
covered by the TerraSAR-X (TSX) satellite- (ascending and descending) and ground-based radar (LiSALab) campaign, we derive $3 \mathrm{D}$ vectors (magnitude and direction) for the Jettan rockslide, Troms, northern Norway (Fig. 1). By this, we attempt to gain new insight into the kinematics and movement patterns of this rockslide (Fig. 1), using calculated 3D vectors, and further, to discuss the possibilities and limitations of $3 \mathrm{D}$ vectors for interpretation. We first compare $3 \mathrm{D}$ surface displacement vectors and mapped surface geological structures, together with slope and aspect directions of the topography, in order to evaluate overall structural and topographical control on rockslide kinematics and
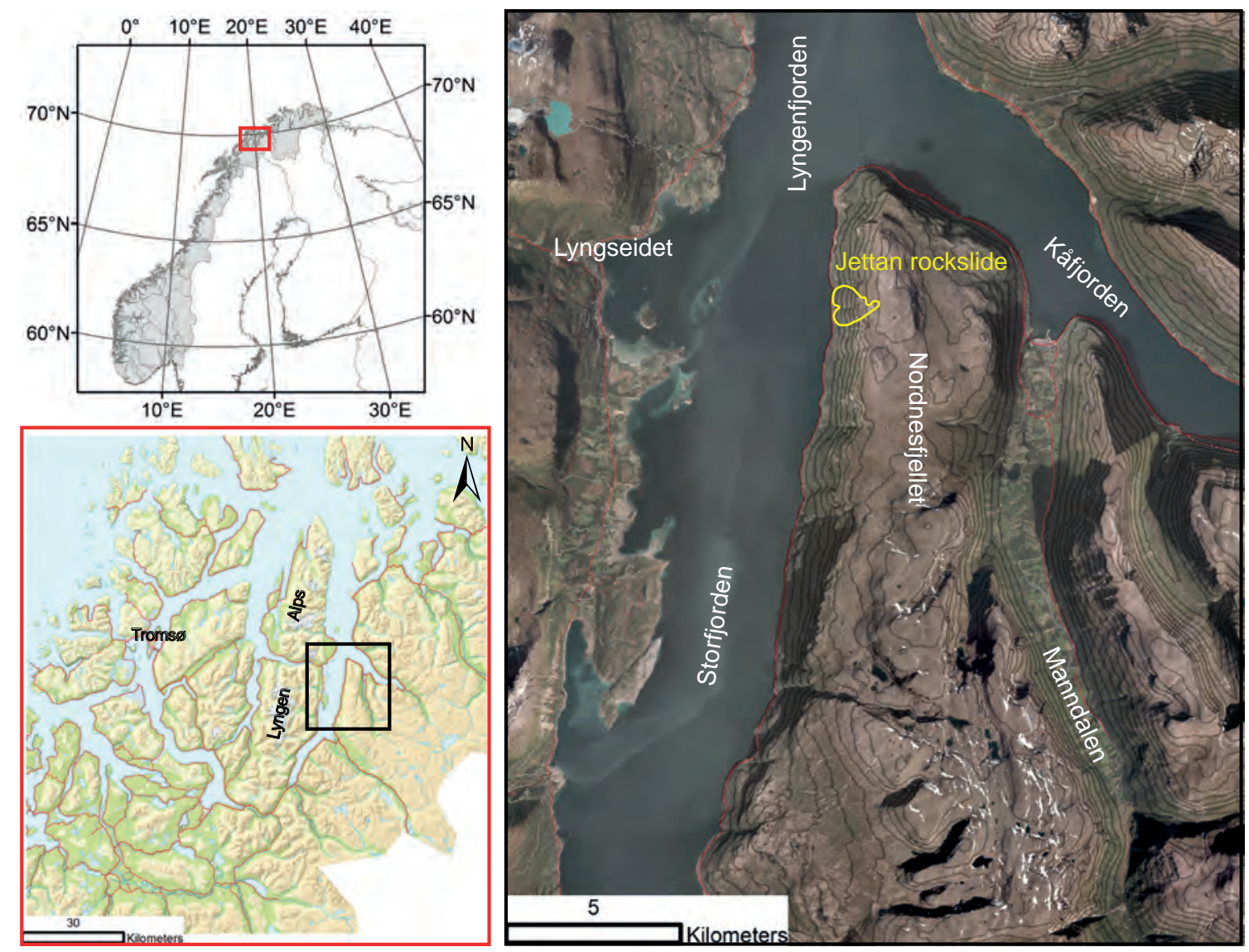

Figure 1. Location of the Jettan rockslide on the side of the mountain Nordnesfjellet, in Troms county, northern Norway, east of the Lyngen peninsula. Contour interval is $100 \mathrm{~m}$. 
interpret subsurface structural architecture. We then consider displacement patterns and compare kinematics in more detail along cross-sections in the northern and southern, and upper and lower parts of the rockslide. By using 3D surface velocity, azimuth, plunge, slope dependency, aspect dependency and strain rate as diagnostic kinematic parameters, we identify areas with displacement into- and out-of-the-slope, and zones of compression and extension. 3D vectors are compared with data from a network of permanent global navigation satellite system receivers (GNSS) on the rockslide. Our approach is applicable to resolving surface kinematics for any landforms and deformation phenomena that are spatially and temporally covered by three or more individual radar datasets.

\section{Geological setting and previous work}

The Jettan rockslide covers an area of $0.9 \mathrm{~km}^{2}$, extending from sea level to $800 \mathrm{~m}$ a.s.l., with a mean gradient of $\sim 30^{\circ}$ on the western fjord-side mountain of Nordnesfjellet in Troms county (Fig. 1), northern Norway. This rockslide has been classified as high-risk due to the severe consequences of a catastrophic failure, which would create a tsunami in the nearby fjord system, threatening populated areas. The total volume of the currently active unstable area bounded by two active back-scarp fractures is c. 5-6 mill $\mathrm{m}^{3}$ (Blikra et al., 2015). The rockslide has been extensively mapped (Braathen et al., 2004; Henderson et al., 2008; Blikra et al., 2009; Skrede, 2013) and studied using tools such as logged borehole cores (Ganerød, 2013, 2014), televiewer data from the boreholes (Elvebakk, 2013, 2014), ground- and satellite-based radar (Lauknes et al., 2010; Kristensen et al., 2011; Kristensen \& Blikra, 2013; Skrede, 2015), 2D electric resistivity, seismic refraction and groundpenetrating radar data (Tønnesen \& Dalsegg, 2006; Rønning et al., 2008), stability analysis (Nystad, 2014), in situ monitoring data (Nordvik et al., 2010), and ground thermal regime and deformation patterns (Blikra \& Christiansen, 2014).

The study area consists of Caledonian bedrock comprising well-foliated gneiss and intercalated marble and schist (see cliffs in Fig. 2B, D \& G; Zwaan, 1988), with an undulating foliation dipping, on average, gently to the northwest (i.e., downslope). The bedrock of the rockslide contains a high frequency of post-Caledonian brittle faults and fractures (Indrevær et al., 2013). It is bounded by two, main, orthogonal, steep, back-scarp fracture sets (Figs. 2A, D \& 3) trending c. NE-SW (in the south) and NW-SE (in the north), respectively (Braathen et al., 2004; Skrede, 2013). Similarly oriented, smaller, orthogonal, steep and planar fracture sets are abundant throughout the rockslide (Fig. 2C, D \& E) and especially below the NW-SE-trending master back-scarp in the north, separating internal orthogonal or wedge-shaped blocks (Fig. 2A). In addition, a subsidiary $c . \mathrm{N}-\mathrm{S}$-striking and steeply W-dipping fracture set (Fig. $3 \mathrm{~A}$ ), which is subparallel to the general hill slope, and numerous other fracture-related discontinuities occur in the unstable area (Fig. 3). In the north, a dominant NW-SE-striking back-scarp fracture and subsidiary NE-SW- and N-Sstriking fractures make up oblique, wedge-shaped blocks, graben-like features and variably tilted fault blocks with internal, disintegrated materials, bounded by synthetic (oblique downslope) and antithetic (toward hillside) fractures/faults (Figs. 2A, B, D, F \& 3). In the southern area, a simpler geometry with gently downslope-dipping foliation is cut by steep, ENE-WSW- and predominating hillside-parallel NNE-SSW-striking fractures (Fig. 3E, F). Notably, some fractures in the south have opened in an oblique manner, more so in the southern than in the northern part of the fractures as documented by Skrede (2013).

The rockslide at Jettan also comprises structurallyrelated surficial geomorphological elements, such as gently downslope- and inward-dipping terraces underlain by moderately-dipping bedrock foliation, fracture-bound scarps, trenches, gullies and ridges (Fig. 3). In total, these features classify the area as an unstable, complex rockslide/field area (Braathen et al., 2004), thus providing a structural framework for interpreting the displacement pattern.

\section{Materials, methods and data processing}

\section{TerraSAR-X InSAR processing}

Using the Norut GSAR software (Larsen et al., 2005), only snow-free scenes from June to October 2009-2014 captured by the space-borne TSX satellite in ascending and descending orbits were multi-looked, $6 \times 6$ and $8 \times$ 6 , respectively. Scenes were processed to two stacks of interferograms, 160 each (see Table 1 in Eriksen et al. (2017), having a temporal baseline of less than 55 days.

The noise level in the interferograms was reduced using Goldstein filtering (Goldstein \& Werner, 1998) and contribution from the atmosphere was filtered by estimating a phase-delay elevation profile for each interferogram (Cavalié et al., 2007). The phase signal in each interferogram was unwrapped using the SNAPHU-unwrapper (Chen \& Zebker, 2001), before manually removing interferograms having unwrapping errors. Assuming the atmospheric contribution to be uncorrelated in time, interferograms from ascending and descending orbits were averaged (stacked) as described in Peltzer et al. (2001), producing two datasets showing a phase mean difference based on all years observed from ascending and descending orbits. Finally, the ascending 


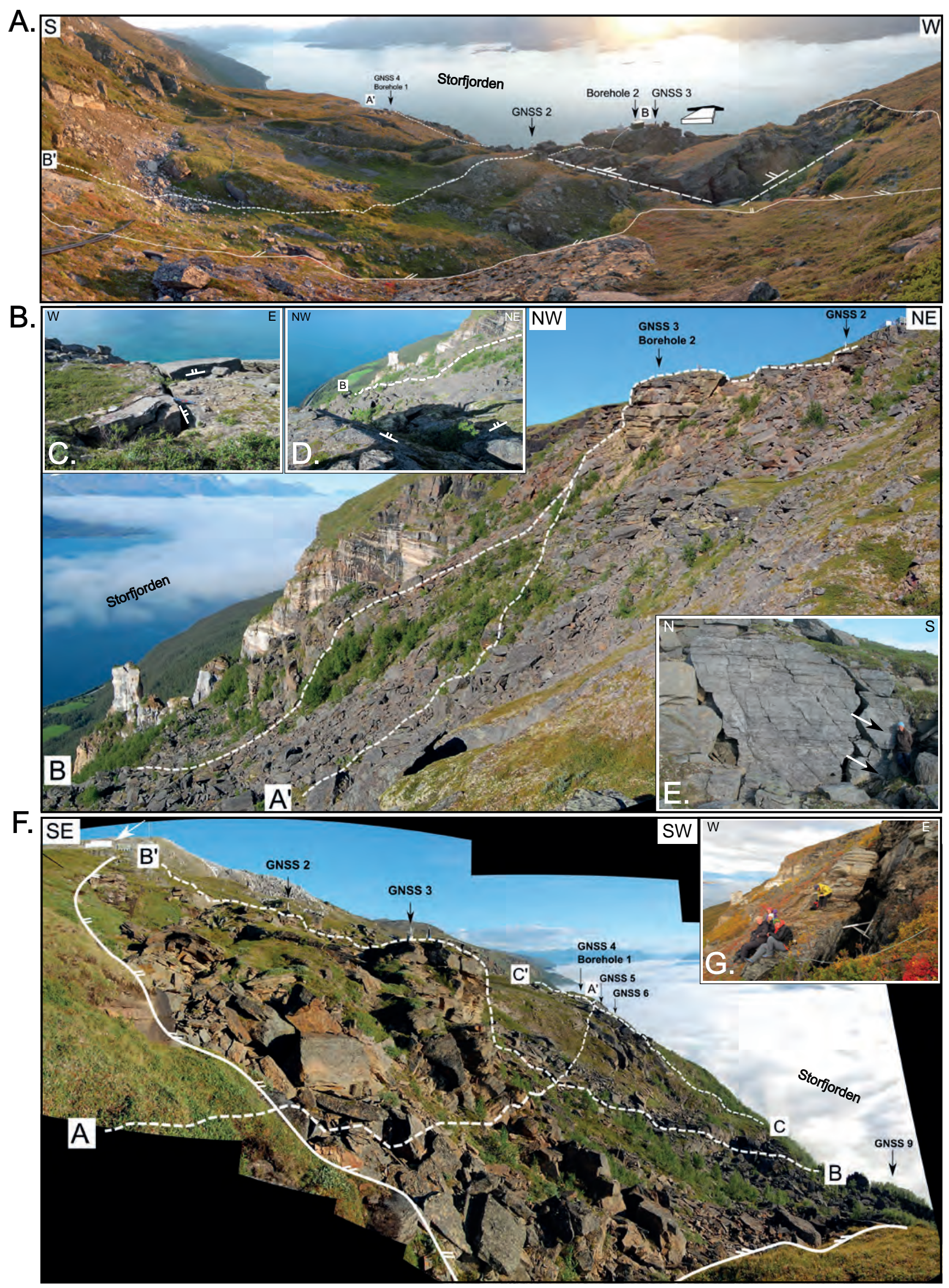


and descending mean phase datasets were converted to mean velocity $\left(\mathrm{mm} \mathrm{yr}^{-1}\right)$ and geocoded to $12 \mathrm{x} 12$ $\mathrm{m}$ resolution in map geometry using a $10 \mathrm{~m}$ digital elevation model (DEM) from the Norwegian Mapping Authority (NMA). Because the interferograms have a temporal baseline of 55 days, they do not connect the snow-free seasons of the individual years. The resulting mean velocity $\left(\mathrm{mm} \mathrm{yr}^{-1}\right)$ is therefore an extrapolation of displacement observed during the time of year having the highest deformation (Blikra et al., 2015), and is thus somewhat overestimated.

\section{Ground-based radar processing}

Ground-based radar data were collected by Norwegian Water Resources and Energy Directorate (NVE) using an instrument from the Italian company Ellegi LISALab s.r.l. Radar data were processed using Ellegi software (Ellegi srl, 2009: LISALab Technology: Methods and feasibility). The radar was located close to sea level below the rockslide, looking up at an angle of $\sim 30^{\circ}$, scanning a sector from ENE to SE. NVE carried out a ground-based radar survey from 07. May-17. September 2013 (133 days) with an acquisition of scenes every 8

Figure 2. Overview of the Jettan rockslide with back-scarp (white solid line) separating stable from unstable bedrock, and locations of GNSS stations and boreholes (marked with black arrows). Crosssections, or parts of cross-sections, $A-A^{\prime}, B-B^{\prime}$ and $C-C^{\prime}$ are marked where they are visible. (A) Outline of the complex graben system in the uppermost active part of northern area. Prominent SW- and $N W$-dipping fracture sets are marked. A topographic terrace occurs to the left, with linear depressions marking fractures dipping NW, orthogonal to the back-scarp at the right. The entire wedge-shaped mass is moving downslope toward WSW (large white arrow). (B) The slope-terrace-slope topography of the northern area with cross-section $B-B$, and transition from northern to southern area marked by cross-section A-A'. In the distance, open NNE-SSWtrending fractures are visible in the southern area. (C) Smallerscale, unstable, bedrock wedges in the upper part of cross-section $C-C^{\prime}$ in the southern area, bound by orthogonal fractures striking WNW-ESE and NNE-SSW, dipping NNE and NW, respectively. (D) Downslope view along major NW-dipping sliding surface bound by orthogonal NE-dipping fracture (in front left) in the northern area, indicating combined planar-failure movement toward NW along intersection lines between the fracture sets. (E) Steep fractures curve into a shallower dip within a few metres. Movement directions (with arrows) are recorded by open cavities, notably here with sliding along the foliation, controlled by foliation and one fracture set. $(F)$ Overview of the chaotic northern area with graben structures in the upper part, and ongoing toppling from scarps. The well-foliated gneiss and intercalated marble and schist (white banded) in the NW-SE trending cliffs in the distance marks the northern extent of the rockslide. Note the $\sim 8 \mathrm{~m}$-long white hut for scale (white arrow in the upper left corner). (G) Close-up view of slope-parallel open fracture set in the southern area, acting as a sliding surface for downslope planar failures. minutes. All scenes acquired during five-day intervals were statically processed to obtain one representative phase image free from atmospheric noise for every five days. The length of the five-day interval was chosen by studying the movement seen in the radar images, as data wrapping does not occur in this time span. The entire dataset of representative phase images were then analysed to provide displacement maps in the form of interferograms and cumulated images. Finally, the accumulated displacement was extrapolated to provide

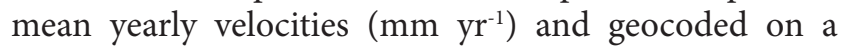
DEM with a spatial of resolution of $1.2 \times 1.2 \mathrm{~m}$.

\section{Geological, structural and geomorphological data}

In order to compare 3D displacement vectors and geological structures, we used structural field orientation data compiled by Skrede (2013) and Hernes (2014). To further investigate the relationship between displacement (kinematics), geological structures and geomorphology, we used 3D displacement vectors from a NNE-SSWoriented, reference longitudinal cross-section A-A' along-strike and parallel to the hillside slope from north to south in the study area. From this reference section, properties of the 3D surface displacement were plotted and analysed including velocity, azimuth, plunge, slope angle, displacement into- or out-of-slope, aspect of the topography and its control on 3D displacement, and strain rate (downslope acceleration and deceleration). For comparison, we investigated internal variations of $3 \mathrm{D}$-surface properties for the northern and southern parts of the rockslide. The same approach as in crosssection $A-A^{\prime}$ was used to investigate variations from upper to lower parts of both the northern and southern parts of the rockslide. In the north we used data originating up to $30 \mathrm{~m}$ on both sides along cross-section $\mathrm{B}-\mathrm{B}$, and in the south, data originating up to $65 \mathrm{~m}$ on both sides along cross-section C-C'. Internal 3D ground displacement was determined along the cross-sections and compared with displacement recorded by GNSSstations, mapped geological structures, geomorphology, slope and aspect. Based on this, we propose geological models to explain the synthesised 3D displacement vector data.

\section{D processing of satellite- and ground-based radar}

Based on the georeferenced ground-based radar dataset and position of radar we calculated the unit vectors for the ground-based radar's LOS vectors for all pixels in the dataset. We also calculated the unit vectors for ascending and descending TSX datasets from radar geometry. Given knowledge of magnitude along LOS for all three datasets, an inversion of a system with 3 linear equations with three unknowns was set up: 


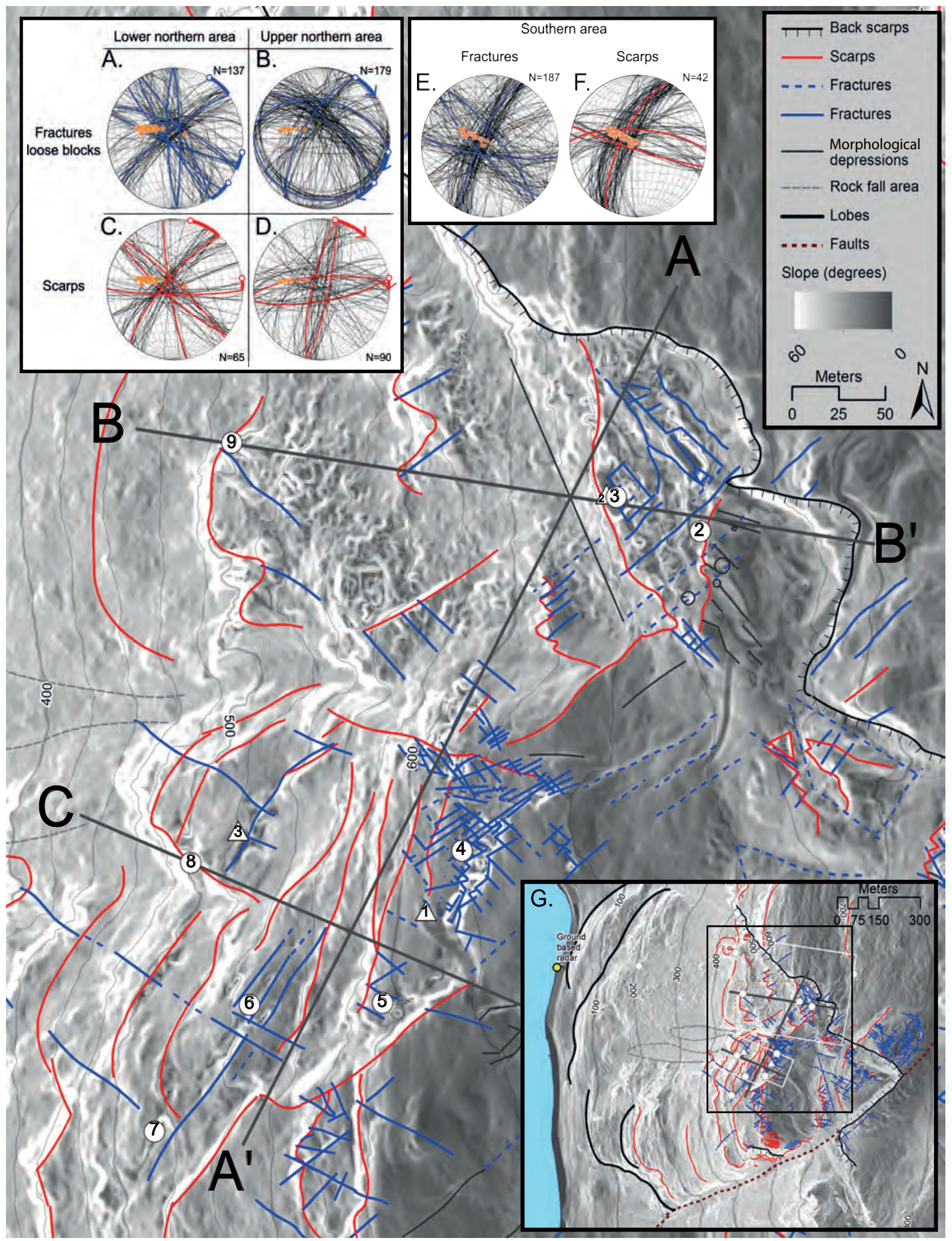

Figure 3. Hillslope map showing geological structures and geomorphological elements in the Jettan rockslide. The northern area is characterised by NW-SE- and NE-SW-trending orthogonal ridges, scarps, depressions and crevasses filled with disintegrated bedrock and block materials (cf., Fig. $2 A, B \& F$ ). In the southern area, N-S- to NE-SW-trending scarps, ridges and depressions are arranged parallel to the hillslope, bounding repeated sets of uniform terraces dipping gently WSW. The map is based on structures mapped by Skrede (2013) and Hernes (2014). GNSS stations marked with circles and boreholes with triangles. (A-D) Structural data from the northern area. Orientation of fractures (great circles) and $3 D$ surface displacement vectors (orange dots) plotted in lower-hemisphere stereograms for blocks and scarps along cross-section $B-B$ ' in lower and upper northern areas, and $(E, F)$ fractures and scarps along cross-section $C-C$ 'from the southern area. Individual fractures are drawn as thin black great circles. The dominant fracture trends are drawn as thicker blue great circles and dominant scarp trends as thicker red great circles. $N$-values indicate number of measurements. Thick blue and red arrows indicate the difference between azimuth of structures in the upper and lower areas. Note the different trends in displacement vectors in the northern and southern areas. (G) Overview of the Jettan rockslide. White rectangles mark the extent of selected mapped geological structures plotted in Figs. 10 \& 11. 


$$
\begin{aligned}
& \boldsymbol{A} * \boldsymbol{x}=\boldsymbol{b} \\
& \boldsymbol{x}=\operatorname{inv}(\boldsymbol{A}) * \boldsymbol{b}
\end{aligned}
$$

For each pixel in the common areas of the ground- and satellite-based radar displacement (input) datasets the resulting combined deformation vector $\boldsymbol{x}$ was calculated. $\boldsymbol{A}$ is a matrix representing the LOS unit vectors of the input datasets as columns, $\boldsymbol{b}$ is a vector with deformation along the LOS direction for the input datasets, and $\boldsymbol{x}$ is the resulting combined deformation vector in 3 dimensions.

We compared displacement patterns from 3D displacement vectors with GNSS stations located in the rockslide area. We computed a mean yearly displacement vector for each GNSS station based on measurements from the same time period as covered by the TSX interferograms.

Combining ground- and satellite-based datasets requires equal spatial resolution. Equal spatial sampling was achieved by resampling the fine resolution groundbased dataset $(1.2 \times 1.2 \mathrm{~m})$ to the coarser resolution of the satellite-based datasets $(12 \times 12 \mathrm{~m})$ using a nearest neighbour approach. InSAR measurements are relative, meaning that the dataset must be referenced to a known velocity for a point or area spatially covered. Usually an area assumed to be stable is used to calibrate the InSAR data. 3D processing demands that all radar datasets to be used are equally referenced to a common area. However, we were unable to find a common stable area covered by all radar datasets. We therefore carried out a rough calibration of input data to the overall trend of the GNSS network using the two-step calibration routine described in Eriksen et al. (2017), before processing 3D displacement vectors. Lastly, we fine-tuned the calibrated InSAR data using an iterative workflow including (1) comparing GNSS displacement from the period covered by InSAR data to averaged velocity, azimuth and plunge from displacement vectors originating from areas close to GNSS-stations 3, 5, 6 and 9, (2) recalibrating InSAR input data and (3) 3D processing using recalibrated input data.

\section{Orthophotos and digital elevation models}

We used orthophotos ( $0.5 \times 0.5 \mathrm{~m}$ and $1 \times 1 \mathrm{~m}$ resolution) provided by NMA and aerial photographs provided by NVE for more detailed interpretation of observed displacement patterns. We produced contour lines, slope maps, aspect maps and hill-shade maps using a DEM based on Light Detection and Ranging (LIDAR) data from 2014 (1 x $1 \mathrm{~m}$ resolution) supplied by NMA. For areas not covered by the LIDAR DEM we used a 10 x 10 m resolution DEM also from NMA (http://data. kartverket.no/download/content/digital-terrengmodell10-m-utm-33).

\section{GNSS}

Displacement data from the GNSS network at Jettan were adapted from NVE. We validate $3 \mathrm{D}$ vectors using GNSS data from four stations at the Jettan rockslide. By using a stable reference frame, data from the Norwegian Permanent GNSS network (Kierulf et al., 2014) were combined with GNSS data from Jettan, as described in Eriksen et al. (2017). We computed the mean annual velocity vectors for GNSS stations based on data from the same time interval (snow-free season from June to October 2009-2014) as covered by the interferograms in the TSX ascending and descending dataset (see table 1 in Eriksen et al., 2017).

\section{Results}

\section{D displacement vectors compared to GNSS network}

After calibration, we compared 3D displacement vectors and GNSS vectors by plotting N-S, W-E and up-down components based on data from the same time periods. The largest deviations are found in the northern part (Fig. 4A, C). Especially the north component of the GNSS 3 area differs by having direction towards the north (positive) in the $3 \mathrm{D}$ data and towards the south (negative) in the GNSS data (Fig. 4A), thereby resulting in some deviations in azimuth of the displacement vectors (Fig. 4E).

The difference between the annual GNSS displacement and the GNSS displacement during the snow-free season, from June to October 2009-2014, caused by seasonal variations, is minor, accounting for a difference of maximum 4 degrees in plunge of GNSS vectors in the $\mathrm{W}-\mathrm{E}$ and up-down plane.

\section{LOS directions used in 3D inversion and sensitivity to displacement}

The orientation of LOS vectors of the input data decides the reliability of the resulting $3 \mathrm{D}$ vectors. The $\mathrm{LOS}$ vectors for ascending and descending TSX data are constant in the rockslide area, but the LOS vectors of the groundbased radar vary (Fig. 5A, B). This variation results in changes in the LOS unit vector matrix $\mathrm{A}$, and the resulting 3D displacement vector $\boldsymbol{x}$ (Eq. 1). By calculating the condition numbers of the LOS unit vector matrix A, we get a relative quality estimate of the $3 \mathrm{D}$ displacement vectors. Condition numbers show how sensitive the resulting $3 \mathrm{D}$ displacement vectors (vector $\boldsymbol{x}$ in Eq. 1) are to variations in the input displacement data along the ground-based radar and TSX ascending and descending LOS vectors (vector $\boldsymbol{b}$ in Eq. 1). The more parallel the 
A.

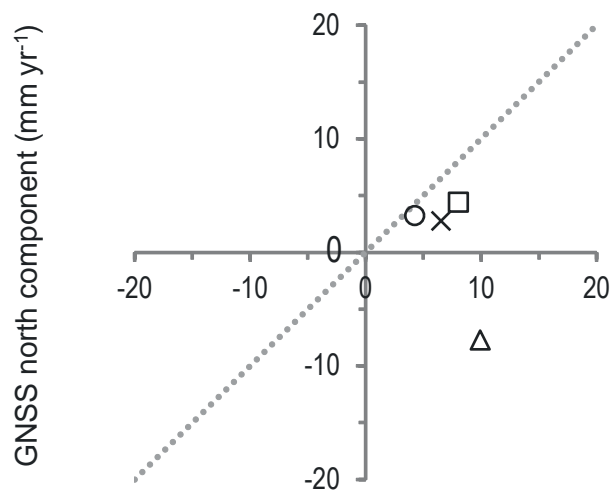

$3 \mathrm{D}$ radar north component $\left(\mathrm{mm} \mathrm{yr}^{-1}\right)$

C.

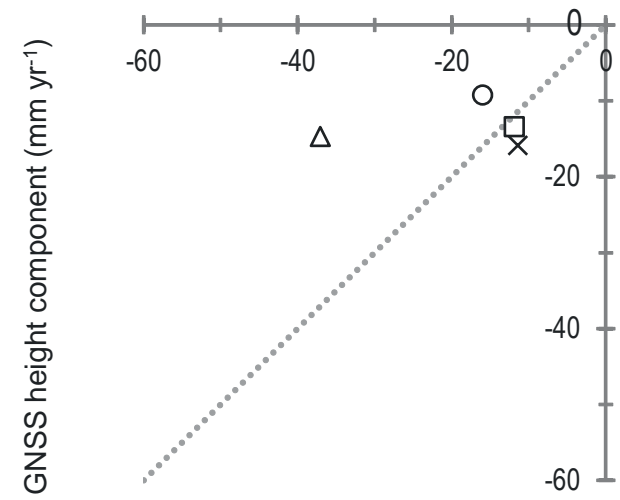

$3 \mathrm{D}$ radar height component $\left(\mathrm{mm} \mathrm{yr}^{-1}\right)$

E.

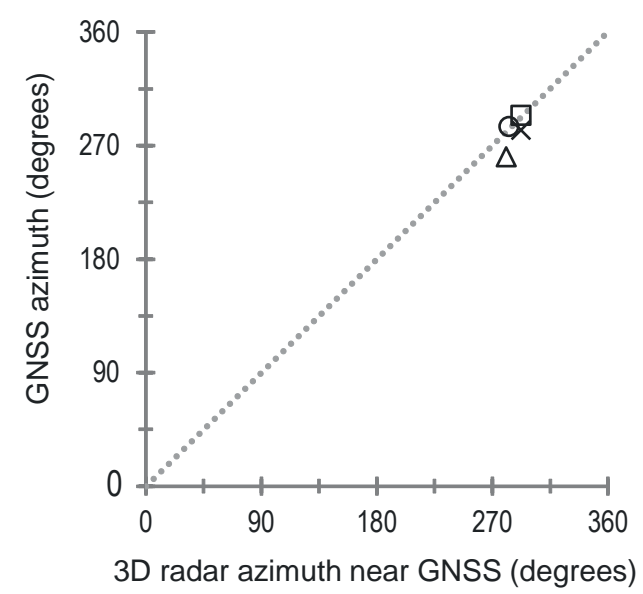

B.

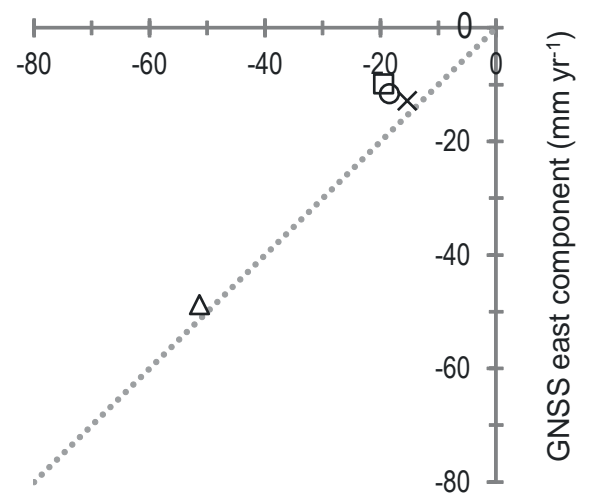

3D radar east component $\left(\mathrm{mm} \mathrm{yr}^{-1}\right)$

D.

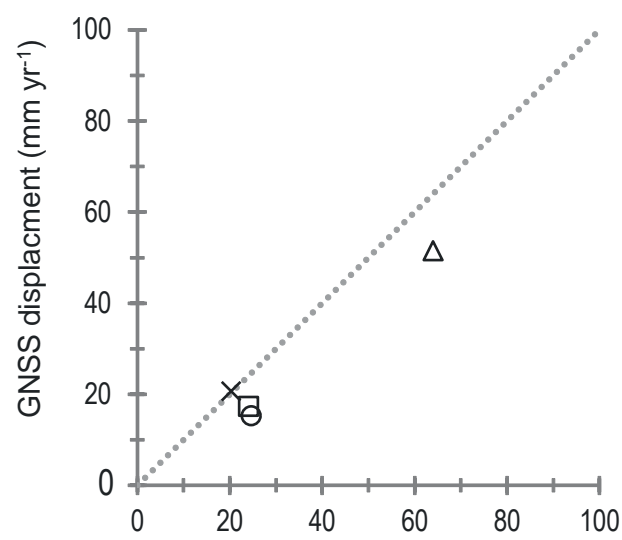

3D radar displacment $\left(\mathrm{mm} \mathrm{yr}^{-1}\right)$

F.

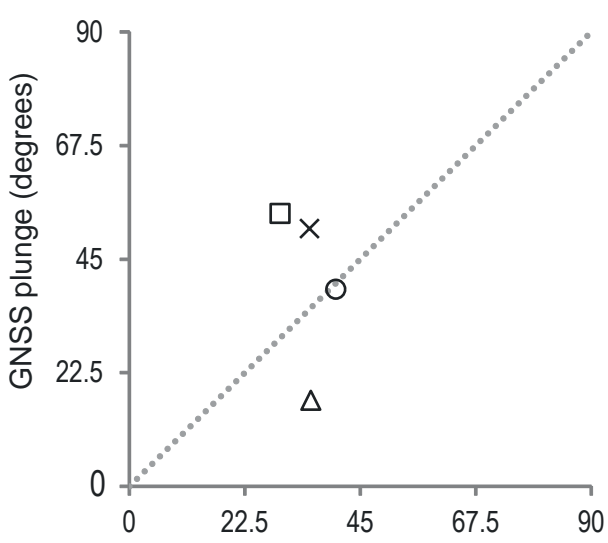

3D radar plunge near GNSS (degrees)

\section{$\triangle$ GNSS YN $3 \times$ GNSS YN 5 \\ 口 GNSS YN 6 GNSS YN 9}

Figure 4. Combined 3D displacement compared to GNSS station displacement from snow-free season (2009-2014). (A) North components. (B) East components. (C) Height components. (D) Length of $3 D$ displacement vectors compared to GNSS vector length. (E) Azimuth of displacement. (F) Plunge of displacement. 


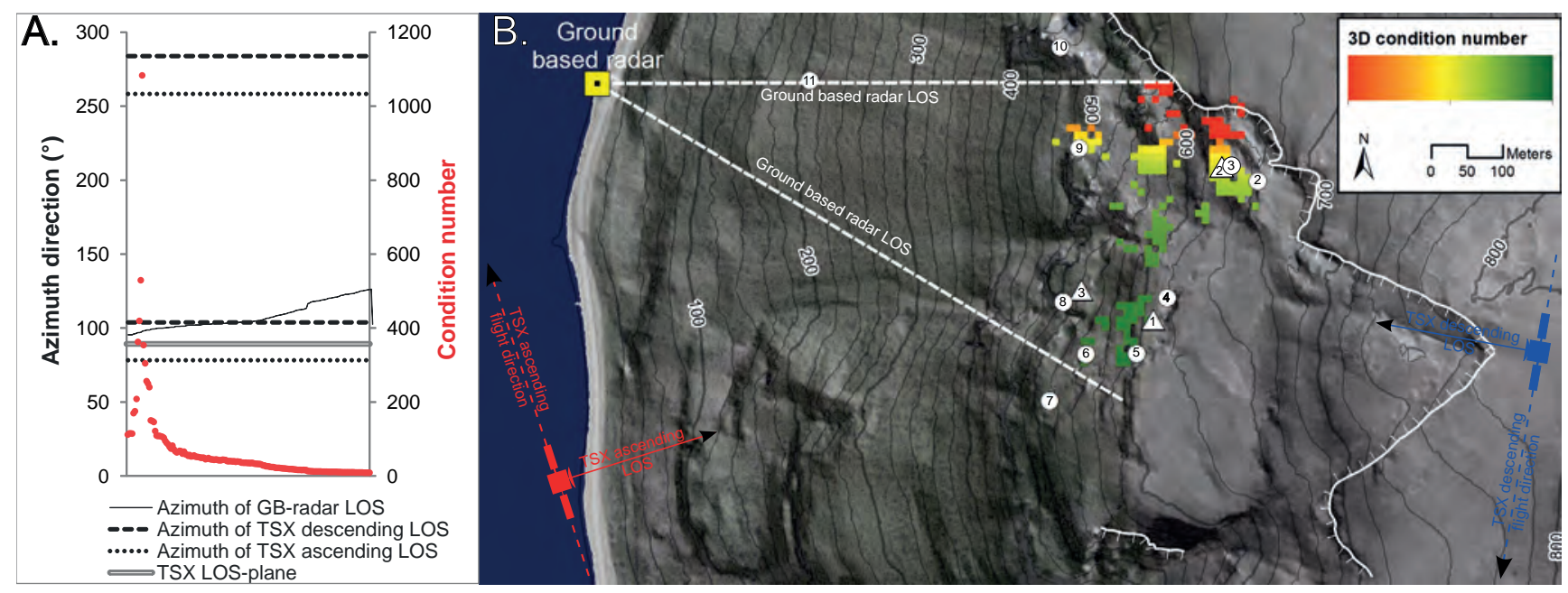

Figure 5. Sensitivity to displacement for 3D inversion at Jettan. (A) Azimuth direction of unit vectors used in the inversion plotted with condition number. (B) Overview of Jettan rockslide and input radar instruments Line-Of-Sight (LOS) directions. Draped raster colors represent condition number diagnosing the $3 D$ inversion. A high condition number means that small errors in the input data will have large consequences for the outcome of the $3 D$ inversion. High condition numbers in $(A)$ are represented by red colors in $(B)$. GNSS stations are marked with circles and boreholes with triangles.

LOS vectors of the input data are, the more numerically unstable (ill-conditioned) the 3D inversion will be, resulting in high condition numbers. Our results show that the condition number increases when the azimuth of the ground-based radar LOS vector approaches the same azimuth direction as the plane span by the TSX ascending and descending LOS vectors (TSX LOS-plane; Fig. 5A). The plunges of the ground-based radar LOS vectors are relatively stable, and therefore do not influence the condition numbers. The $3 \mathrm{D}$ vectors with the highest condition numbers are located in the north of the dataset, coinciding with the northernmost GNSS station (GNSS 3 ), with the most pronounced deviations occurring in the north component (Fig. 5B).

\section{Displacement trends vs. structure}

Results from 3D processing show that displacement is highest in the upper and northernmost areas of the rockslide close to GNSS 3 (Fig. 6). Here, blocks in the graben-structure bounded by the NW-SE-striking back-scarp and subsidiary NE-SW fractures, reveal a maximum velocity of $\sim 65 \mathrm{~mm} \mathrm{yr}^{-1}$ (Figs. 3, $6 \& 7$ ). The calculated 3D surface-displacement vectors azimuth directions are pointed toward WNW $\left(280^{\circ}\right.$; Figs. $4 \mathrm{~B}, 6$ \& 7), indicating that both NW-SE- and NE-SW-striking fractures may have contributed as controlling factors (Fig. 3A-D).

As observed in map-view (Fig. 6), the overall displacement velocity decreases from north to south in the longitudinal cross-section A-A' (red line in Fig. $8 \mathrm{~A}$ ), whereas, by contrast, internal variations in the northern and southern areas show the opposite pattern, with velocity increasing towards the south (grey lines in Fig. 8A). A corresponding change in azimuth of 3D displacement vectors is observed, from dominantly W-directed $\left(\sim 275^{\circ}\right)$ in the north (Fig. $8 \mathrm{~B}$ ), to fairly uniformly WNW-directed $\left(\sim 287^{\circ}\right)$ in the south (Fig. 9A), although internally trends do exist (grey lines in Fig. 8B).

In the southern area (Fig. 6), velocity is highest in the lower part, i.e., $\sim 35 \mathrm{~mm} \mathrm{yr}^{-1}$, and $\sim 25 \mathrm{~mm} \mathrm{yr}^{-1}$ in the upper part. The azimuth of the 3D displacement vectors is fairly uniform and NW-directed $\left(290^{\circ}\right)$. Displacement direction is orthogonal to the NE-SW-trending fractures and scarps (Fig. 3E, F), indicating a clear structural control on the displacement direction.

The general plunge pattern of 3D displacement vectors shows a pattern of uniform and steeper plunges in the southern area compared with more shallow and varied plunges in the northern area (Fig. 9B and inset histogram, Fig. 8C).

\section{Displacement trends vs. topography}

The relationship between aspect and surface displacement was analysed and calculated by subtracting the azimuth direction of 3D displacement vectors from aspect for each pixel (Fig. 9C). This shows that there is a general pattern of $3 \mathrm{D}$ displacement azimuth trending more towards the north than the hillslope aspect given by more positive than negative values in Fig. 9C, inset histogram and Fig. 8F. Furthermore, we observe almost the same topographic control on displacement direction in the northern and the southern area, given by the same variance in aspect dependency (Fig. 9C inset histogram). This means that the azimuth direction of $3 \mathrm{D}$ vectors in both areas varies about equally with respect to aspect. 


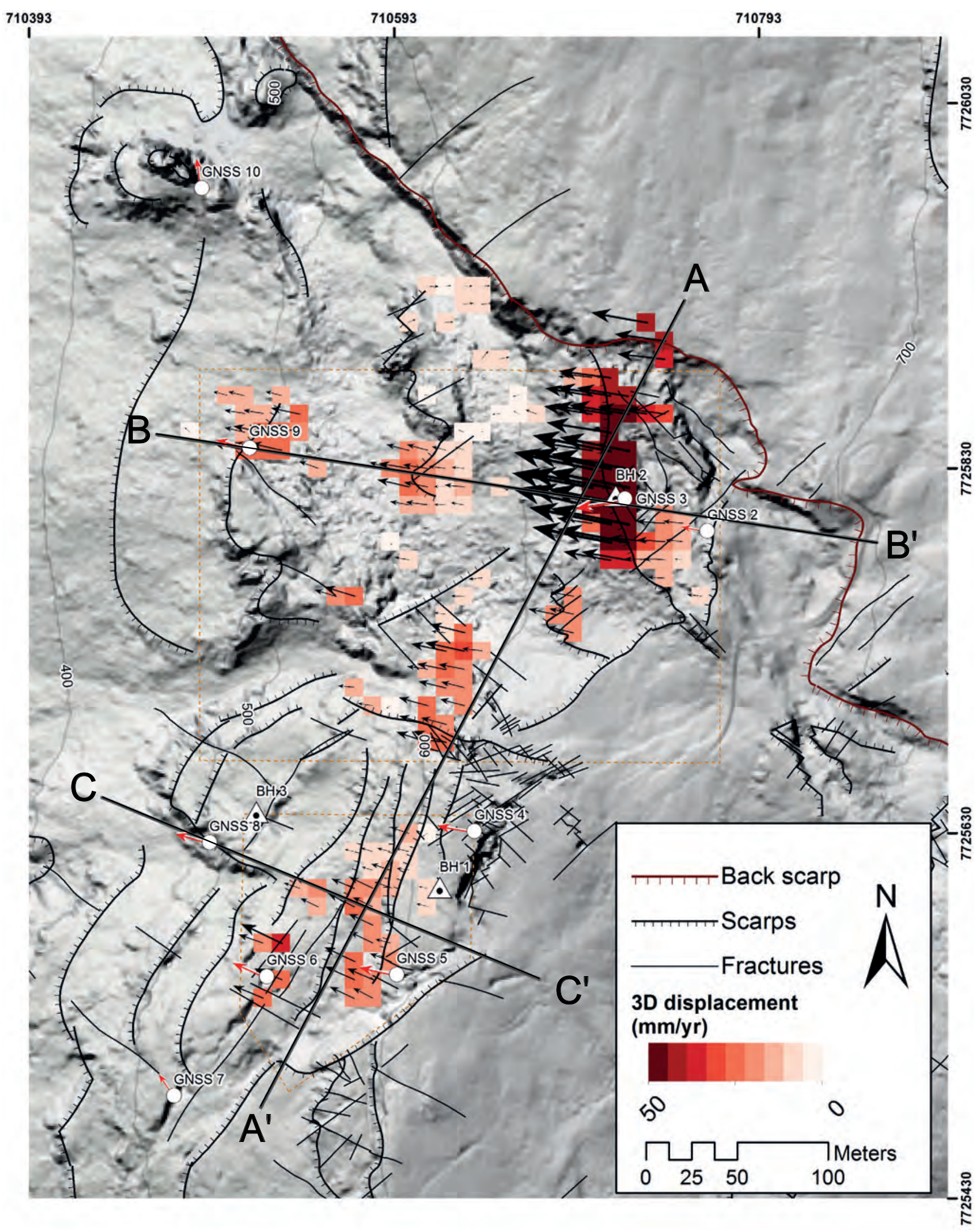

Figure 6. 3D displacement vectors (black arrows) and GNSS displacement vectors (red arrows) from the Jettan rockslide, with geological structures and geomorphological elements. Direction (azimuth) and length ( $m m y r-1$ ) of $3 D$ vectors and GNSS vectors are comparable. The mean yearly velocity of $3 D$ vectors is also given by red to white raster. Locations of cross-sections $A-A^{\prime}, B-B$ ' and $C-C$ ' are marked by black solid lines. Locations of boreholes $(B H)$ and GNSS stations are marked. The extent of the map is shown in Fig. $3 G$. 


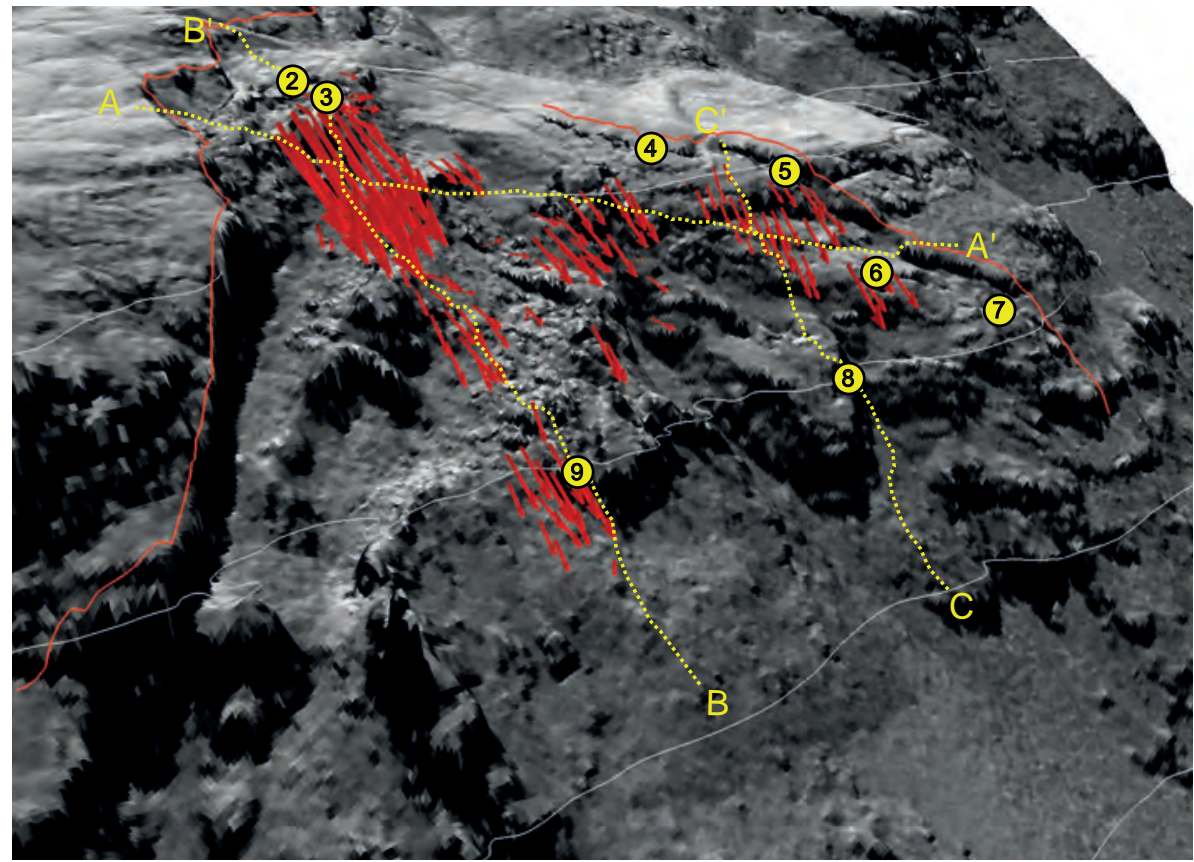

Figure 7. 3D displacement vectors and slope map draped on a digital elevation model (DEM) of the Jettan rockslide. Dark colors represent steep terrain, light colors are flatter areas. Back-scarp marked with red line. GNSS stations marked with yellow circles and cross-sections with stippled yellow lines. DEM and slope maps are based on $1 \times 1 \mathrm{~m}$ resolution LIDAR data from 2014 supplied by the NMA.

Displacement into- and out-of-the-slope was analysed by subtracting the plunge of displacement vectors from slope gradient. Our results show variable patterns both in the northern and in the southern areas (Fig. 9D). Notably, the southern area has a larger continuous area of displacement into-the-slope. In the north, the plunge of $3 \mathrm{D}$ vectors varies more between into- and out-of-theslope (Fig. 9D inset histogram).

\section{Discussion}

Below we first discuss the reliability (validation) of the calculated 3D surface displacement datasets, and then proceed with analysing the $3 \mathrm{D}$ data and their relation to structures and geomorphology in the Jettan rockslide, as a basis for proposing a tentative rock-slope failure model.

\section{Effect of aligned LOS plane and LOS vectors}

By comparing 3D displacement vectors and displacement data from the different GNSS stations in the Jettan rockslide, the most pronounced deviation between the two measurement techniques is shown by the north component in the area near GNSS station 3, while most of the other GNSS stations display smaller deviations (Fig. 4A). This deviation may be due to intrinsic properties of the $3 \mathrm{D}$ inversion in this area, such as the spatial alignment of LOS vectors of the input datasets yielding numerically unstable 3D inversions. The result is higher condition numbers in the northern area than in the southern, as shown above (Fig. 5B). Illconditioning of the 3D inversion in this area will affect the accuracy of the N-S component because this is the direction orthogonal to the ground-based LOS when parallel with the TSX ascending-descending LOS plane (Fig. 4A). The ill-conditioning of the 3D inversion does not necessarily affect the sensitivity in the W-E updown plane (Fig. 4B). On the contrary, the deviation in the $3 \mathrm{D}$ north component observed for GNSS 3 is not found for GNSS station 9, even though it is located in the northern area (Fig. 4A), also with high condition numbers (Fig. 5B). This deviation may be due to a difference in monitoring technique. While the GNSS station 3 observes displacement from a single point in a block, radar observes averaged displacement from $12 \mathrm{x}$ $12 \mathrm{~m}$ areas. When comparing point measurements from GNSS stations to spatially averaged measurements from radar for a complex and highly fractured rockslide like Jettan, one should expect some deviations (see Eriksen et al., 2017).

\section{Effect of steep topography}

The topography within the rockslide at Jettan is undulating, with numerous fracture-related scarps, ridges and gullies, and terraces underlain by gently dipping bedrock foliation (Figs. 3, $6 \&$ 7). 3D displacement vectors can only be calculated for areas where the ground-based and the two satellite-based radar datasets overlap. Due 

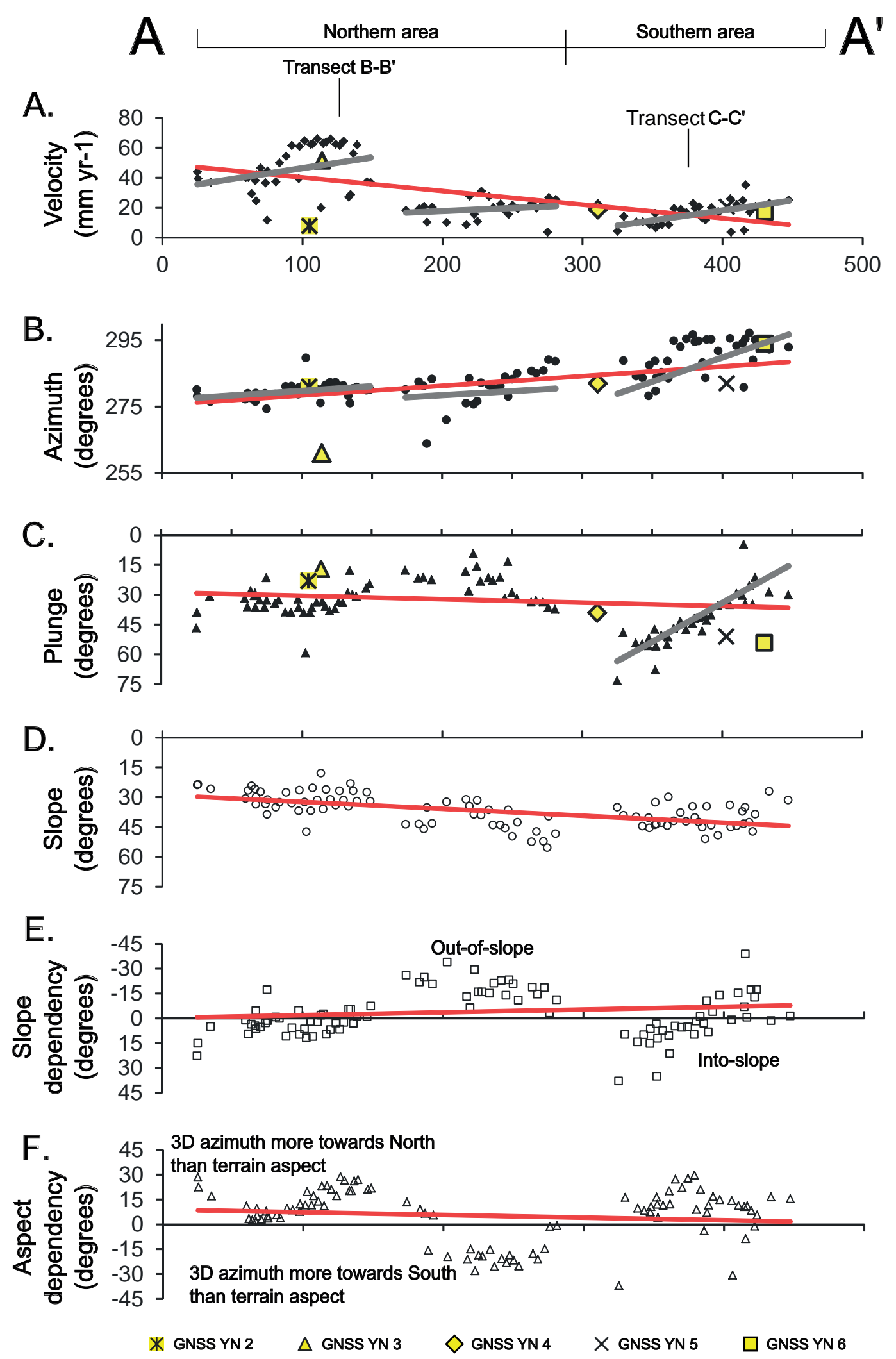

Figure 8. Properties of $3 D$ vectors along cross-section A-A' and nearby GNSS stations, including (A) mean yearly velocity, (B) azimuth of displacement, (C) plunge of displacement, (D) slope of topography, (E) plunge of displacement compared to slope giving displacement into- or out-of-slope (slope dependency), and (F) displacement direction towards north or south compared to aspect (aspect dependency). Grey lines indicate linear internal trends. The boundary between the northern and the southern areas (vertical stippled line) is marked, together with locations of cross-sections $B-B$ ' and $C-C$ '. 


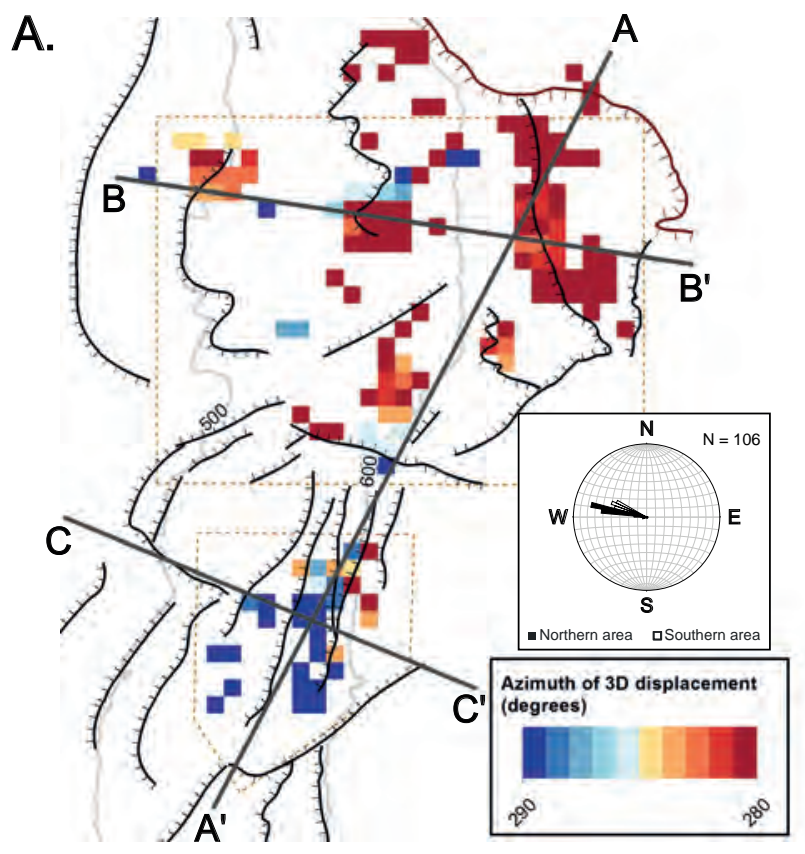

C.

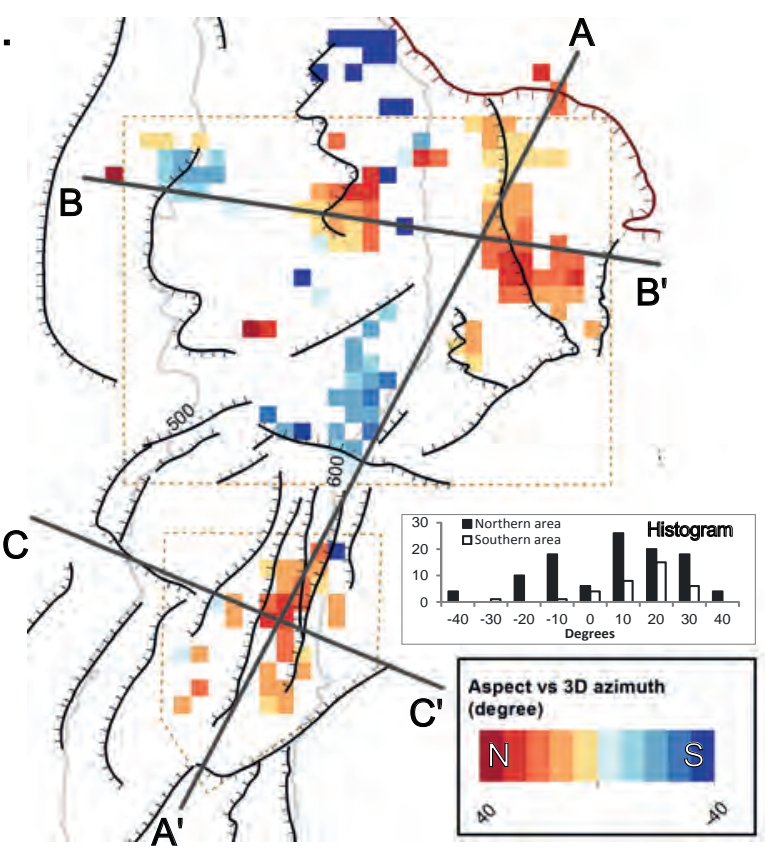

B.

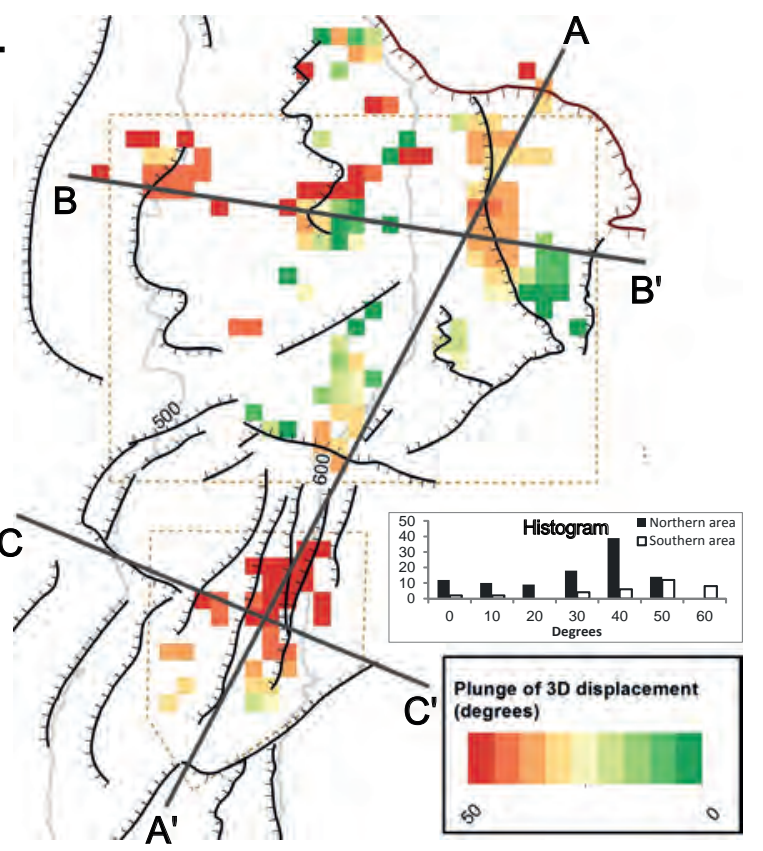

D.

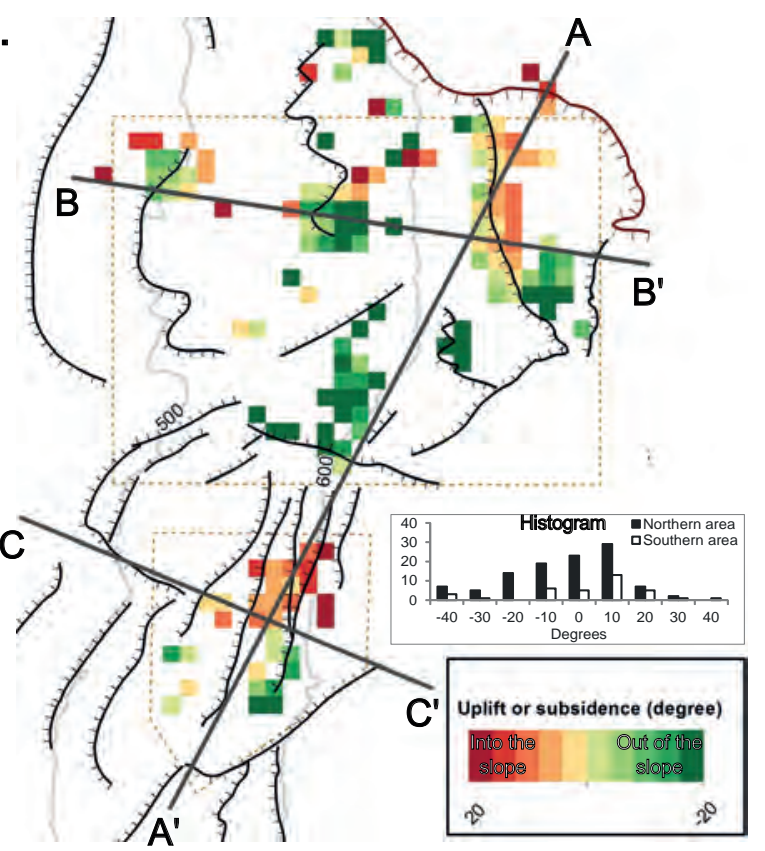

Figure 9. Properties of $3 D$ displacement vectors and relation to topography and structures for the Jettan rockslide. Inset rose diagram and histograms show deviations in main azimuth and plunge trends of $3 D$ displacement vectors in the northern and southern areas of the rockslide. Extents of the northern and southern areas are marked with brown stippled lines; cross-sections $A-A$ ', $B-B$ ' and $C-C$ ' marked with dark-grey lines. (A) Azimuth of $3 D$ displacement vectors. (B) Plunge of $3 D$ displacement vectors. (C) Difference between azimuth of $3 D$ displacement vectors and aspect of the topography, giving aspect dependency for displacement. Positive values (red color) mean displacement more towards north than aspect, zero means equal azimuth direction, negative values (blue color) mean displacement more towards south than aspect. (D) Areas with displacement into-the-slope (red color) and out-of-the-slope (green color) from comparing plunge of $3 D$ displacement vectors with slope of the topography. Positive values mean displacement into-the-slope, zero values mean equal plunge, negative values mean displacement out-of-the-slope.

to its position at almost sea level and the undulating topography of the rockslide, the ground-based radar limits the overlapping areas to steeper parts of scarps and the lowermost convex part of terraces. GNSS stations 3 and 9 are located close to the edge of scarps with steep surface-relief below (Figs. $3 \& 7$ ). 3D vectors selected for comparison with these GNSS stations therefore capture the mean displacement mostly from blocks in steep topography, whereas the GNSS stations record point measurements of more gentle topography on terraces above the scarps. The height component may therefore be overestimated, which could explain the deviation between the two measurement techniques (Fig. 4C). Other implications of overestimated vertical movements for calculated 3D vectors may be that they display higher velocity (Fig. 4D) and steeper plunge (Fig. 4F) than 


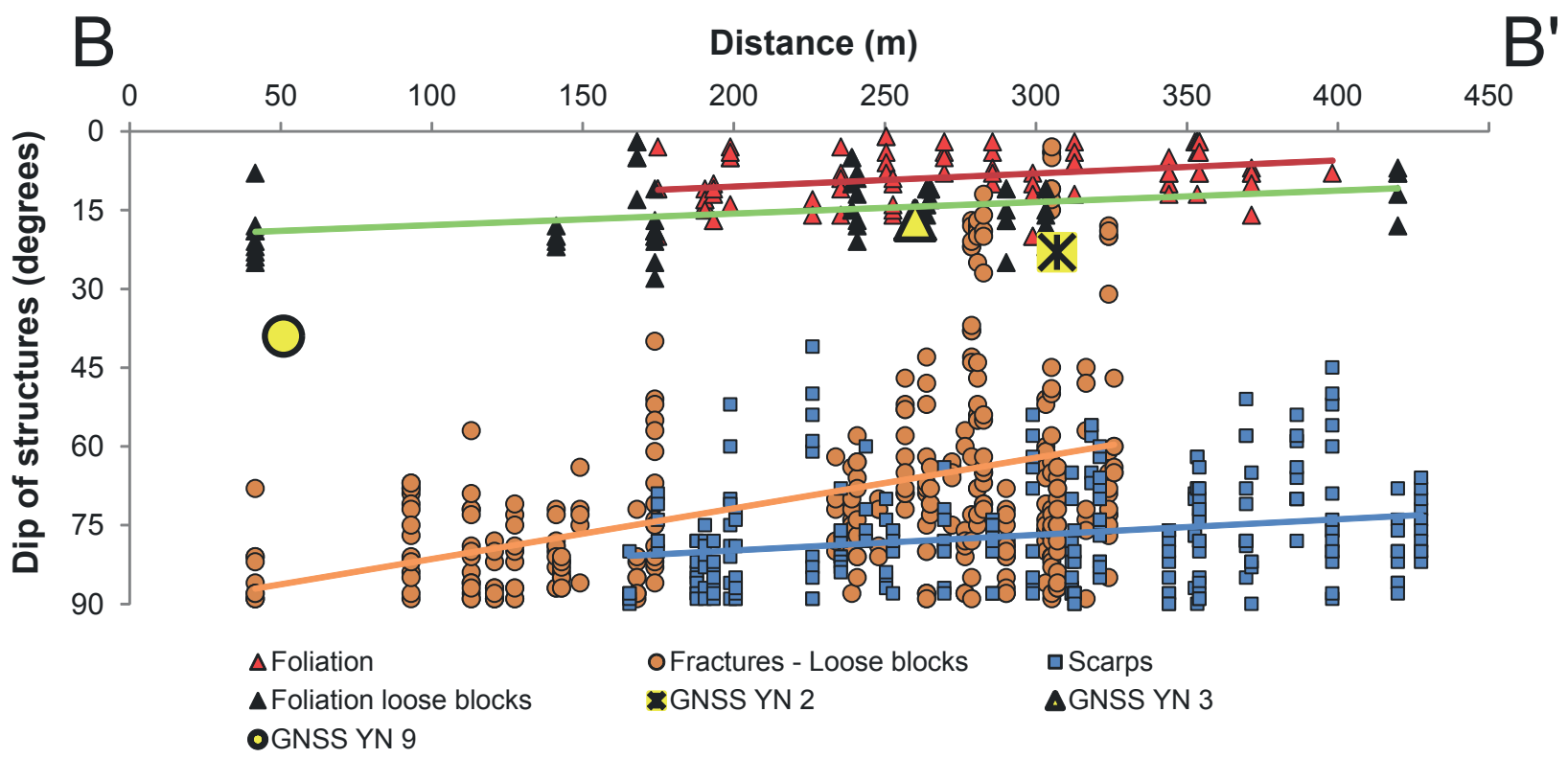

Figure 10. Dip of fractures, scarps and foliation from a 320 m-wide buffer along cross-section B-B'. See Fig. $3 G$ for extent of buffer. Mean plunge of GNSS station from snow-free seasons (2009-2014) is marked for GNSS stations 2, 3 and 9.

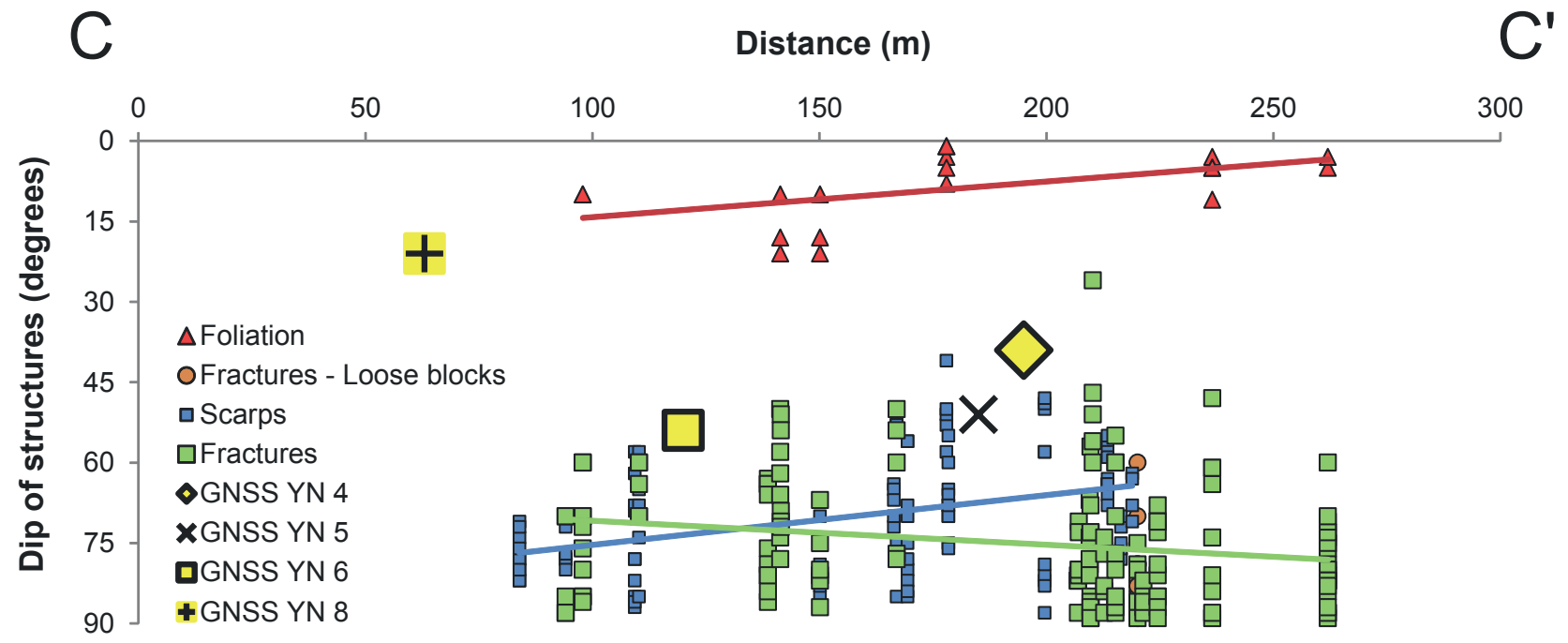

Figure 11. Dip of fractures, scarps and foliation from a $130 \mathrm{~m}$-wide buffer along cross-section C-C'. See Fig. $3 G$ for extent of buffer. Mean plunge of GNSS station from snow-free seasons (2009-2014) is marked for GNSS stations 4, 5, 6 and 8.

recorded by the GNSS stations. However, the effect of a deviating height component is not so severe for GNSS 5, possibly because this station is not located on the edge of a scarp. Nevertheless, we find the 3D data acceptable for interpreting surface displacement, although some caution must be taken regarding higher condition numbers affecting the $\mathrm{N}-\mathrm{S}$ component in the northern area, the difference in measuring technique being due to spatial sampling (point vs. area) and over-representation of sampling of steeper areas in the 3D data.
Effects of temporal and spatial sampling

Spatial and temporal sampling of satellite-based radar datasets differ from the ground-based radar dataset used in the 3D inversion. For example, InSAR processing of TSX satellite data is based on temporal sampling (acquisition) every 11 days, from June to October 20092014, while processing of ground-based radar data is based on continuous acquisitions every 8 minutes, from 10. May -15 . September 2013 (128 days), although only averages for every five days were used here. Previous data and results of in situ instrumentation show that the deformation pattern at Jettan follows a repeated 


\section{Northern area}

A.

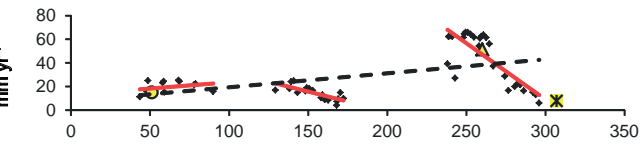

B.

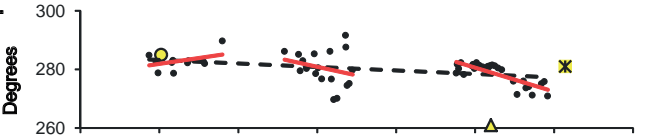

C.

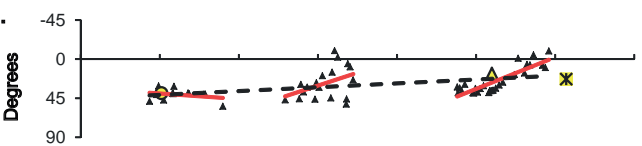

D.

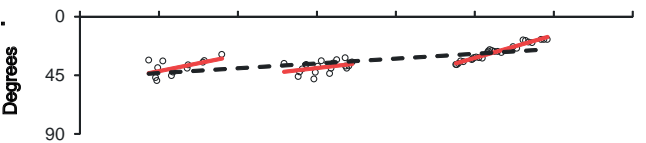

E.

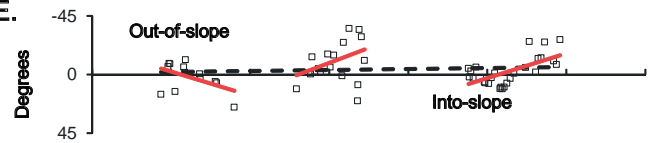

F. 45 3D azimuth more towards North

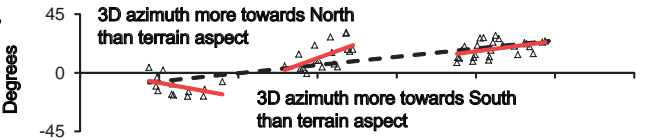

G.

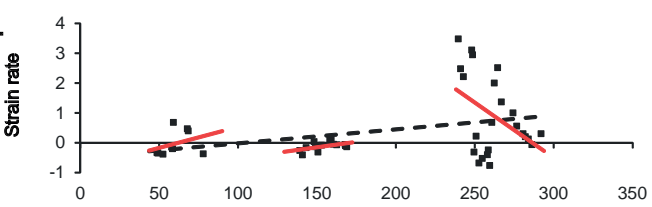

Velocity

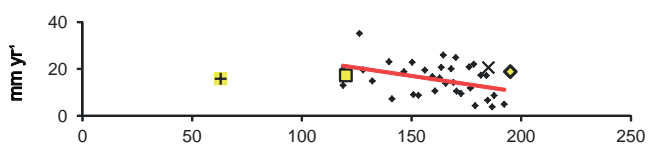

Azimuth

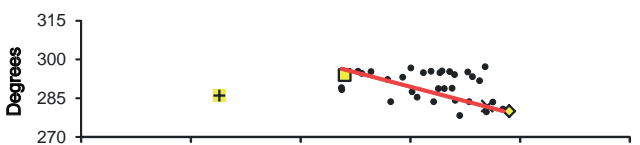

Plunge

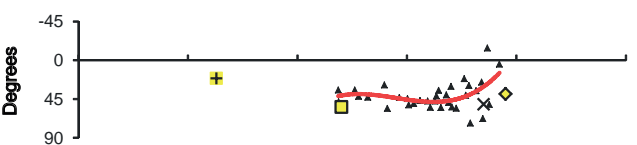

Slope

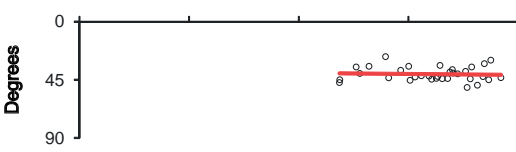

Slope dependency

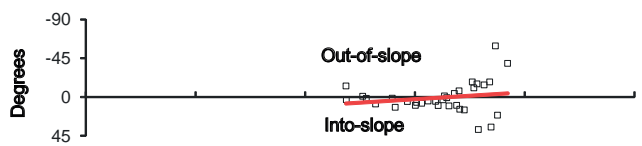

Aspect dependency

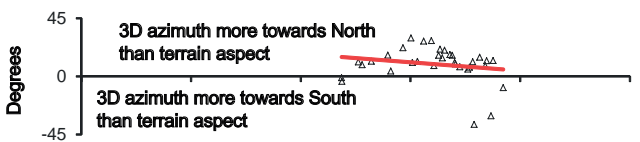

Extension

Compression

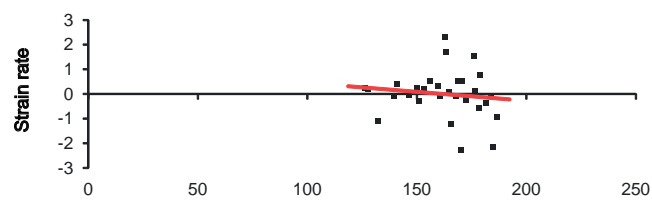

$B^{\prime}$

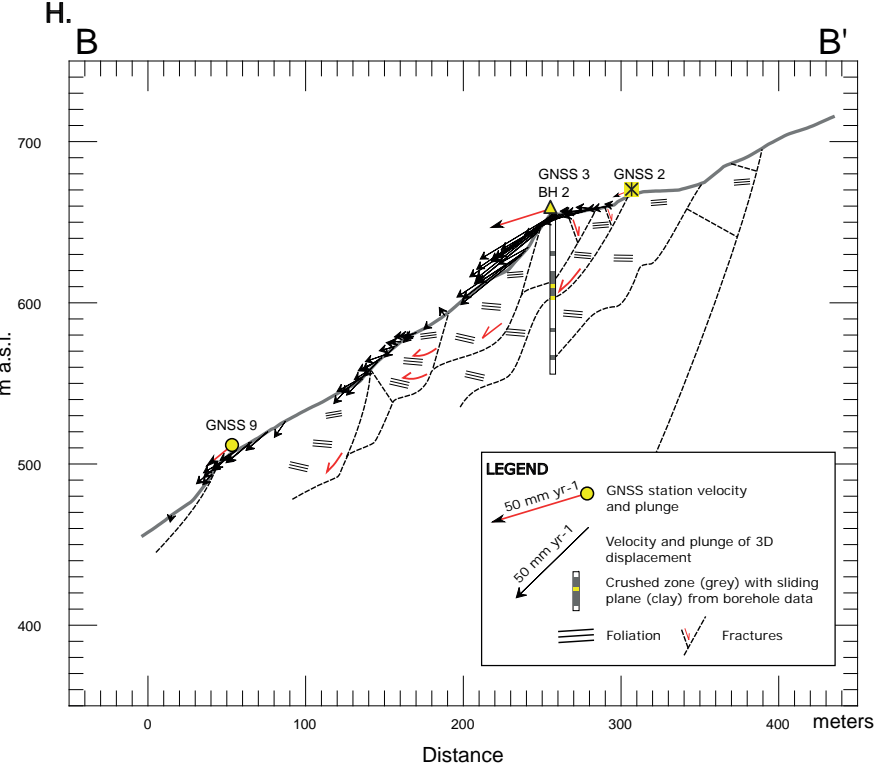

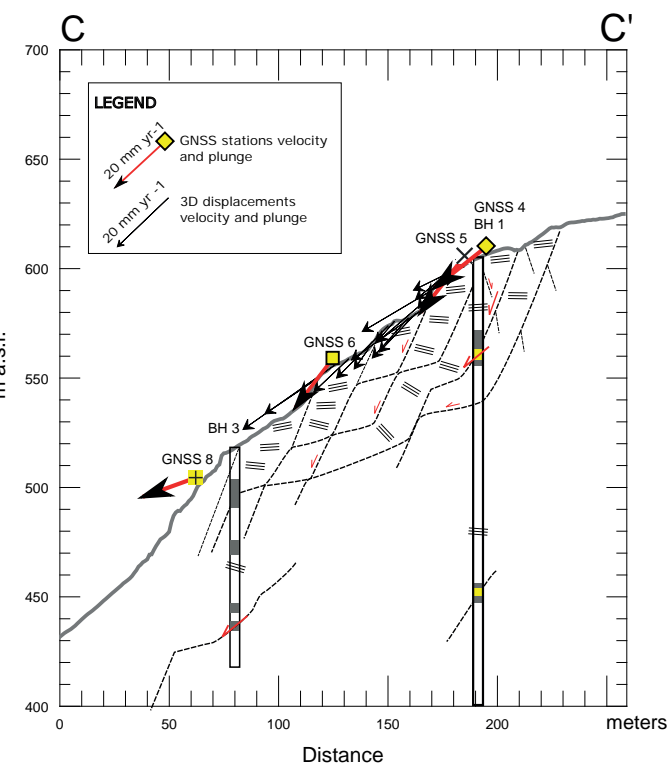

GNSS YN $6+$ GNSS YN 8 O GNSS YN 9

Figure 12. Properties of $3 D$ displacement and relation to topography, GNSS stations and borehole data, along cross-sections B-B' and C-C' from the northern and southern areas of the Jettan rockslide, with proposed rock-slope failure models. Three mechanisms are inferred from the cross-sections: (1) Back-rotation can be imaged as a step-wise structural pattern formed by steep NW-and SE-dipping fractures cutting through the foliation, and/or following a more gently dipping foliation, leading to gradually more back-rotated blocks at depth, with movement along fractures and foliation into the surface. (2) Wedge-failure collapse along planar intersection lines between NE-and SW-dipping fracture sets. (3) Planar failure. (A) 3D displacement velocity, (B) azimuth and (C) plunge, (D) slope of topography, (E) relation between slope and plunge of displacement, $(F)$ relation between aspect of topography and azimuth of displacement, $(G)$ downslope velocity gradient (strain rate) denoting areas with compression and extension, and $(H)$ geological cross-sections with data from DMS and core logging of boreholes (Elvebakk, 2013, 2014; Ganerød, 2013, 2014), mapped geological structures (Skrede, 2013), 3D surface displacement draped as black arrows and GNSS displacement as red arrows. All structures and displacements are projected into the trend of the cross-sections. 
distinctive seasonal pattern (Blikra et al., 2015). Blikra et al. (2015) found an abrupt increase to high deformation in spring, lasting over the summer, then a gradual reduction after establishment of snow cover, and finally a reduction to almost no deformation during winter. Because of this annually repeated velocity signal, and because all three datasets are from the snow-free season, we assume the same mean annual velocity for the TSX data as for the ground-based radar data, and thus consider the mean velocities to be comparable and suitable as input to the $3 \mathrm{D}$ inversion. However, the computed mean annual velocity for all three radar datasets used in the $3 \mathrm{D}$ inversion is most likely overestimated, because the datasets originate from the time period when in situ instrumentation records the highest deformation in the repeated seasonal deformation pattern (Blikra \& Christiansen, 2014). The difference in spatial sampling is resolved by down-sampling the ground-based radar dataset to the $12 \times 12 \mathrm{~m}$ pixel size of the TSX data from the ascending and descending orbit.

\section{D surface displacement data related to geologi- cal structures}

By combining InSAR data from TSX ascending and descending satellite orbits to $2 \mathrm{D}$ InSAR displacement data, Eriksen et al. (2017) divided the most active parts of the Jettan rockslide into northern, southern and upper areas each having different displacement patterns. These areas largely coincide with the mapped and interpreted structural domains that segment the rockslide (Skrede, 2013). In the following sections, we use 3D surface displacement vectors (Fig. 6) to discuss further differences in displacement patterns between the northern and the southern areas, and their upper and lower parts, as well as internal variation. Finally, we compare and correlate $3 \mathrm{D}$ vector data with geological structures (Figs. 3, 10, 11) and geomorphological elements (Fig. 3), using constructed geological crosssections (see overview in Fig. 6, and cross-sections in Figs. 8 \& 12).

Going from north to south the calculated velocities decrease along the longitudinal cross-section A-A' (Fig. $8 \mathrm{~A}$, red line), and the contrasting internal variation with increasing velocity towards the south (Fig. 8A, grey lines) may be what has caused larger fractures in the southern area to move and open in an oblique manner, as noted by Skrede (2013). The obtained variations in $3 \mathrm{D}$ displacement data along the cross-section $\mathrm{A}-\mathrm{A}^{\prime}$ showing repeated sets of internal variation, can be used to infer the presence of segmented (compartmentalised) domains within the rockslide.

The change in azimuth direction of 3D displacement vectors from a northern trend in the southern area to a southern trend in the northern area (Fig. 9A) is more prominent when plotted in a cross-section (Fig. $8 \mathrm{~B}$ ). The internal variations in azimuth direction in the southern area of cross-section A-A' coincide with a trend in both velocity (grey line in Fig. 8A), and plunge (grey line in Fig. 8C), indicating that $3 \mathrm{D}$ displacement vectors with azimuth directions towards the north have steeper plunge and higher velocity.

Steeper plunge towards the south may be controlled by the presence of steeply west-dipping fractures, and/or combined NW-SE- and NE-SW-striking fractures that may have acted as sliding surfaces there (Braathen et al., 2004).

\section{The northern area}

In the varied terrace-slope-terrace topography of the northern area, the following general trends appear when moving downslope: (1) decrease in 3D surface displacement velocity (black stippled line in Fig. 12A), (2) steeper plunge (black stippled line in Fig. 12C), (3) transition from displacement into-the-slope to outof-the-slope (red colors in the upper part and green in the lower part of B-B' in Fig. 9D), and (4) transition of internal downslope velocity gradient (strain rate) from overall extension (positive) to compression (Fig. 12G). In advance, the $3 \mathrm{D}$ displacement data show an internal repeated stepping pattern. The general trends indicate overall surface extension and displacement into-theslope in the upper part and surface compression and displacement out-of-the-slope in the lower part of the northern area. Displacement into-the-slope in the upper part may be controlled by the major NW-SE-trending back-scarp bounded by a frontal graben structure with several NE-SW- and NW-SE-trending orthogonal depressions and blocks, some having ongoing toppling (Figs. 2A, B, F, 3 \& 7). By contrast, the out-of-the-slope displacement in the downhill area may be due to a much simpler structure with dominant NW-dipping ridgeparallel fracture sets. We interpret the reduced downslope velocity in the lower northern area to be an effect of more intact underlying bedrock, providing a stabilising structure, as proposed by Blikra \& Christiansen (2014) for the area in the south near GNSS 7.

Regarding the azimuth of the 3D displacement vectors, we observe a weak and variable trend from WNWdirected in the upper part to NW-directed in the lower parts of cross-section B-B' (Fig. 12B). This change in azimuth values suggests a change in the direction of displacement on different sliding surfaces, i.e., likely controlled by attitudes of fractures and/or foliation surfaces (Skrede, 2013). A possible explanation is rotation of subsurface brittle fractures from the upper area to the lower area, as indicated by the arrows on the stereoplots of fractures in loose blocks and scarps (Fig. 3C rotated to Fig. 3A, and Fig. 3D to Fig. 3B). For example, the more varied, WNW-directed, displacement pattern in the upper part of cross-section B-B' may be explained by a complex kinematic interaction in a graben zone between two orthogonal fracture sets. This 
fracture architecture would favour downslope failure of 'non-daylighting' wedges, i.e., slip along the line of intersection of the orthogonal fractures and rotation of wedges out-of-the-slope (topple) or into-the-slope (Figs. 3 \& 7; Stead \& Eberhardt, 2013). However, a calculated, approximately NNW-oriented and 40 degree plunge of the intersection line in the northern area, based on the two dominant fracture sets there (Fig. 3A-D), deviates from the presumed WNW-directed displacement pattern if wedge-failure acted alone. Thus, additional failure mechanisms must also be active in this area.

The aspect values of the topography and their relation to surface displacement (aspect control) (Fig. 9C) also vary from the upper part to the lower part of cross-section B-B' (black stippled line in Fig. 12F). The change from north-directed aspect displacement to south-directed displacement from the upper part to the lower part of cross-section B-B' (Fig. 12F), is the opposite trend compared to the azimuth of the 3D vectors (Fig. 12B), suggesting that slope aspect has little influence on the 3D displacement. However, since condition numbers (see Fig. 5), describing $3 \mathrm{D}$ inversion quality, increase towards the north in our dataset, they would affect the reliability of the 3D azimuth direction data. Therefore, caution is required when interpreting azimuth and aspect dependency on 3D displacement in the northern area.

Regarding aspect values and topography of the Jettan rockslide, we observe an internal downslope increase in displacement velocity in the northern area coinciding with steeper topography (Fig. 12A, D; red lines), and a downslope steepening in plunge of 3D displacement vectors (Fig. 12C; red lines). Hence, the slope may be a controlling factor for displacement. On the other hand, plotting dip of geological structures mapped by Skrede (2013) (Fig. 3), measured along the cross-section B-B' in the northern area of the Jettan rockslide, shows that the average dip of fractures, scarps and foliations increases downslope (Fig. 10). This trend of steeper dip is also recorded by GNSS stations 2, 3 and 9 (Fig. 10). Therefore, we suggest a combined topographic and structural control on displacement in the northern area.

By subtracting dip of topography from plunge of 3D displacement vectors, variations of displacement intoslope and out-of-slope take place inside individual domains along cross-section $\mathrm{B}-\mathrm{B}^{\prime}$ in the northern area. We interpret the internal change from out-of-slope to into-slope in the middle and upper domains (red lines in Fig. 12E at $129-172 \mathrm{~m}$ and $238-296 \mathrm{~m}$ along B-B') to be an effect of a forward rotational movement, possibly due to an ongoing toppling process. The opposite trend is observed in the lower part of cross-section B-B' ( 43$90 \mathrm{~m}$ in Fig. 12E), and could indicate compression due to stacking of blocks in thrust-imbricated zones. Similar processes have been described from nearby rockslides at Nomedalstinden (Husby, 2011) and Nordmannviktinden (Braathen et al., 2004).

\section{The southern area}

Compared to the northern area, the southern area of the Jettan rockslide (Fig. 6; cross-section C-C') displays a much more uniform 3D displacement vector pattern. In particular, we observe only one set of downslopeincreasing displacement velocity (Fig. 12A), and a corresponding steeper plunge of the $3 \mathrm{D}$ displacement vectors in the upper part, constant plunge in the middle part and a shallower plunge in the lower part of $\mathrm{C}-\mathrm{C}^{\prime}$ (Fig. 12C; curved trend). Structural orientation data for surface-related fractures along cross-section $\mathrm{C}^{-} \mathrm{C}^{\prime}$ support the shallowing plunge of $3 \mathrm{D}$ displacement vector data from GNSS stations (Fig. 11), thus verifying that these structures have acted as sliding/movement surfaces along the cross-section C-C.' Moreover, field observations of back-rotated slide blocks (Eriksen, 2013), observations of steep fractures becoming listric (Fig. 2E; Skrede, 2013) and outcrops of two, low-angle, foliationparallel detachments in the cliff face (Braathen et al., 2004), all indicate that similar structures may be present at depth, and likely were responsible for the calculated $3 \mathrm{D}$ displacement vectors and patterns observed.

The southern areas of the Jettan rockslide define a more coherent and intact bedrock structure than the northern area. The main foliation dips gently $(<30$ degrees) downslope, and is cut by the dominant NNESSW-striking brittle fracture set which is parallel to the hillside, and the subsidiary and ENE-SSW-striking fracture set (Fig. 2G). We interpret the 3D vector data, yielding a more uniform NW-movement pattern, to reflect a displacement pattern controlled by repeated sets of planar and/or listric, slope-parallel, back-rotated surfaces/discontinuities. When steep fractures cut through more gently dipping foliation surfaces, the geometric result may be a step-wise structural pattern with gradually more back-rotated blocks (or foliation surfaces) at depth; cf. Braathen et al. (2004) and examples from outcrops in Figs. 2E, G \& 12. In some places, 3D displacement data suggest movement along antithetic fractures and possibly back-rotated foliation into the hillside.

\section{Subsurface structure and kinematics}

Inferring subsurface displacement patterns of the Jettan rockslide based on calculated surficial 3D movement vectors is more difficult for the northern area than for the southern one, since the northern area is geologically more complex and may carry evidence of a combination of several deformation (failure) mechanisms. Differential Monitoring Stability (DMS) monitoring and borehole data from the northern area show that most displacement is directed toward the northwest and takes place on surfaces located between 40 and $50 \mathrm{~m}$ depth in borehole 2 close to GNSS 3. Logging by televiewer suggests that this displacement is a result of interactions between heavily fractured zones trending NW-SE and dipping 
steeply towards SW, and rather steep foliation dipping 55-75 degrees mostly towards west (Elvebakk, 2014). Alternatively, displacement may be controlled by an interaction between the two, orthogonal, steeply SW- and NE-dipping, fracture sets. If similar subsurface structures exist like those observed at the surface, this would increase the probability of a wedge-failure collapse in the northern area.

In the southern area, the most favourable sliding surfaces would be the ductile Caledonian foliation, alternatively, brittle NW- and/or SW-dipping fractures that may have become listric and merged into the foliation at depth (cf., Fig. 2E). From borehole 1 in the southern area, such foliation-parallel fractures occur at 20 to $40 \mathrm{~m}$ depth (azimuth towards $\mathrm{W}$ and plunge between $15-20^{\circ}$ ), together with a fracture set dipping $\sim 40^{\circ}$ towards NW, documented by televiewer at $\sim 45 \mathrm{~m}$ depth (Elvebakk, 2013). DMS data confirm that most of the deformation takes place at this depth (crushed zone), at $\sim 45$ to 46 $\mathrm{m}$, directed towards the west (Blikra et al., 2015) (see red arrow at $45 \mathrm{~m}$ depth in borehole 1 in the southern area) (Fig. 12). We interpret the crushed zone to be the main sliding surface in the upper part of the southern area of Jettan. In the lower part of the southern area, the main sliding surface is located much deeper, at a depth of between 70 and $80 \mathrm{~m}$ on west-dipping, foliationparallel surfaces, based on televiewer data from borehole 3 (Elvebakk, 2014). DMS data show that the highest cumulative deformation is taking place between $\sim 77$ and $87 \mathrm{~m}$ depth, congruent with a crushed zone at $\sim 80$ to 81 m (Ganerød, 2014).

The downslope shallowing in plunge of 3D displacement vectors in the southern area (Fig. 12C) is thought to be controlled by a decrease in dip of fractures as observed from the surface (green line in Fig. 11) and the intersection lines between steeper fractures, and/or rotated structures, due to the presence of listric (curved) fracture sets.

Although not documented in later measurements, an unexpected displacement pattern was recorded by the DMS column in borehole 1 in the upper part of the southern area. Below $45 \mathrm{~m}$ depth, the displacement was towards east (Blikra et al., 2015). This trend was very weak and inside the uncertainties, but, as noted by (Nystad, 2014), it may be an effect of back-rotation due to active movement along a listric fault/fracture at $\sim 150$ m depth (Elvebakk, 2013; Ganerød, 2013). We suggest that this could be a large-scale version of antithetic movement along rockslide-bounding fractures and foliation as indicated by observations on the surface (Fig. 2E) and discussed above. Such back-rotation of blocks and antithetic movement could create inward extension and produce local uplift near scarps, and potentially, uplift of the main terrace located above cross-section C-C', as documented by Eriksen et al. (2017) using 2D InSAR.
Permafrost is not present in any boreholes in the Jettan rockslide, although local patches of sporadic permafrost in deep fractures have been documented (Blikra \& Christiansen, 2014). Therefore, some of the observed 3D surface displacement in the Jettan rockslide may have originated from shallow deformation due to permafrostcontrolled rockslide deformation.

\section{Rock slope failure model based on surface and subsurface Structures}

In a structurally controlled, complex field-type rockslide as at Jettan, various structural models may be applied to account for the 3D displacement data obtained, and local failure mechanisms can be proposed (Braathen et al., 2004; Stead \& Eberhardt, 2013). The surface displacement signature of a deforming rockslide is the sum of all displacements taking place at depth. Usually, sparse subsurface information about displacement patterns and geological structures make it hard to construct a reliable geological/failure model. For the Jettan rockslide, however, calculated 3D displacement vectors and surface geological data supplemented by data from boreholes provide an important input for proposing tentative sliding surfaces at depth, and form the basis for suggesting a failure model for the northern and southern areas of the Jettan rockslide (Fig. 12H).

We favour a 'complex field' model (Braathen et al., 2004) for the unstable rockslide at Jettan comprising (1) internal zones of extension in the upper northern area, with backward-rotational movements along listric, possibly discontinuous, sliding surfaces at depth (cf., Rasmussen, 2011), possibly combined with (2) internal zones of compression related to stacking of unstable, rotated blocks similar to that of thrust-imbricate zones (Braathen et al., 2004; Husby, 2011). In this tentative model for Jettan, the main orthogonal, NW-SE and NE-SW-striking, brittle, post-Caledonian fractures, and corresponding smaller-scale sets, define a fracture architecture that would favour downslope wedgefailure collapse (Fig. 7; Stead \& Eberhardt, 2013). This mechanism includes slip along the line of intersection of the orthogonal fractures, which is again closely perpendicular to the subsidiary NNE-SSW-striking fractures. Such a scenario would favour the foliation as the main gliding surface, or alternatively, some of the steep planar fractures that become listric with depth (as observed in Fig. 2E), and possibly merge into gently NW-dipping foliation surfaces (see Fig. 12H). Such a change in subsurface structure may produce, or be accompanied by, inward rotation of antithetic blocks, thus creating inward extension, local uplift near the scarps, and compression in the downward section of the rockslide, due to buttressing or similar effects (see Braathen et al., 2004; Blikra \& Christiansen, 2014). 3D displacement vectors show a trend from displacement into-the-slope in the upper part to out-of-the-slope in 
the lower part of the northern area (cross-section B-B'), with a shallowing of the $3 \mathrm{D}$ vector plunge in the southern areas (cross-section C-C') (Fig. 12C, E). A listric faulting mechanism may have been active on both a large and a small scale, as verified from field outcrops where steep fractures curve into a lower dip within metres (Fig. 2E), and cut across or merge with the main foliation.

This model may be applicable to a 'worst case scenario' for slope failure (Nystad, 2014) if rock masses down to $45 \mathrm{~m}$ depth (5.5-6 million $\mathrm{m}^{3}$ ) between the two main fracture scarps (Figs. 3 \& 7) move by wedge failure synchronously downslope. A wedge-failure mechanism could also account for possible smaller orthogonalshaped blocks in the northern and central parts of the unstable area, where local and more varied movement patterns occur and a number of potential brittle fractures may function as gliding surfaces (Figs. $3 \& 6$ ).

Another reliable model and accompanied displacement mechanism is planar failure, which is inferred for the southern area, where one dominant, NW-dipping, backscarp fracture set provides the only controlling structure for downslope movement along $\mathrm{W}$ - to NW-dipping, slope-parallel fractures, in conjunction with minor, transverse fractures perpendicular to them.

\section{Conclusions}

1) The use of remote sensing techniques to understand the slope processes and controlling factors of unstable rockslides is an evolving discipline. This paper combines three InSAR radar datasets to calculate 3D displacement vectors and exploits 3D displacement properties such as velocity, azimuth, plunge and strain rate for the Jettan rockslide, Troms, northern Norway. The calculated 3D displacement properties can be related to topography (i.e., displacement into- or out-of-the-slope and aspect), structure and geomorphology of the rockslide, where the

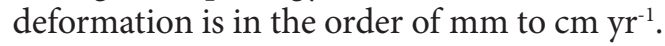

2) We compare 3D displacement vectors and their properties in map view and cross-sections, with displacement data from GNSS stations and information on host-rock fabrics and borehole data, in order to discuss the structural and geomorphological architecture, and displacement patterns.

3) Movement patterns derived from 3D displacement vectors differ between spatial domains of the Jettan rockslide. In the northern area, $3 \mathrm{D}$ vector azimuth directions point toward WNW, and plunge angles are shallow and spatially discontinuous. In the southern area, azimuth directions are directed toward NW, and have steeper and spatially more uniform plunge.
These data indicate subdivision of the rockslide into segmented domains.

4) In the northern area, the $3 \mathrm{D}$ vector attributes can be explained by the presence of gentle, downhill-dipping, bedrock foliation in a complex graben system, bound by steep, fracture-related, orthogonal, NW-SE- and NE-SW-trending ridges, scarps, terraces, depressions and crevasses, showing a repeated, stepping, 3D displacement pattern. This orthogonal fracture pattern may also be present at depth, providing a controlling effect on displacement upon stepped and discontinuous sliding surfaces, produced by the interaction of gently downslope dipping foliation and steep orthogonal fractures. An observed downslope decrease in $3 \mathrm{D}$ displacement velocity and increased compression may be related to imbricate stacking of fractured blocks. Changes in $3 \mathrm{D}$ vector azimuths from a WNW trend in the upper part to a NW trend in the lower part, is linked to changes in azimuth of both ductile foliation and brittle fractures.

5) The attributes of $3 \mathrm{D}$ displacement vectors, such as their slope dependency and the plunge of $3 \mathrm{D}$ vectors compared to slope of terrain, suggest displacement into-the-slope in the upper part, and out-of-the-slope in the lower part, possibly along alternating steep planar fractures and fractures becoming listric gliding surfaces with increasing depth. Where fractures merge into gently NW-dipping foliation surfaces, the resulting back-rotation of antithetic blocks may give displacement inward along rotated foliation-parallel fractures. Smaller internal variations in plunge (intoand/or out-of-the-slope) indicate forward rotational movement, possibly due to ongoing toppling processes.

6) In the southern area, $3 \mathrm{D}$ displacement vectors show a uniform, downslope (WNW-directed) increase in velocity and shallowing of plunge, indicating that displacement here is concentrated along more continuous, hillslope-parallel,fracture sets than in the north. Uniform, NE-SW- to NNE-SSW-trending scarps, ridges and depressions arranged parallel to the hillslope, and gently WNW-dipping terraces suggest a more homogenous displacement pattern. The data further suggest movement on step-wise, planar and/ or listric sliding surfaces at depth, giving way to backrotation of blocks, possibly creating inward extension and local uplift near the scarps.

7) We propose a structure-controlled rock-slope failure model for the unstable rockslide area of Jettan, comprising alternate planar- and wedge-failure collapse along one or more of the orthogonal fracture sets that have evolved from planar into curved (listric) fractures at depth, combined with fractures that merge with gently downslope-dipping foliation surfaces, enhancing rotation of separate fault blocks. 
8) Using the Jettan rockslide as a case study, we show how 3D displacement vectors from ground- and satellite-based InSAR data may contribute to understanding structural and topographic control on rockslide kinematics, and ongoing displacementfailure processes. The approach used is applicable for studying any displacement phenomena spatially and temporally covered by three radar datasets.

Acknowledgements. We are thankful for good comments from reviewers which helped improve the manuscript. We also thank Geoffrey D. Corner for comments on this manuscript and thorough copy-editing. This research was supported, as part of a $\mathrm{PhD}$ programme, by Troms County Council, project number 217720 and grant number RDA12/165. TerraSAR-X satellite data were provided by DLR (projects GEO0565, GEO0764, and GEO2497). We acknowledge the hard-working people at NVE in Manndalen for help with valuable assistance, logistics and accommodation during fieldwork.

\section{References}

Bardi, F., Raspini, F., Ciampalini, A., Kristensen, L., Rouyet, L., Lauknes, T., Frauenfelder, R. \& Casagli, N. 2016: Space-Borne and GroundBased InSAR Data Integration: The Åknes Test Site. Remote Sensing 8 (237), 25 pp. https://doi.org/10.3390/rs8030237.

Berardino, P., Costantini, M., Franceschetti, G., Iodice, A., Pietranera, L. \& Rizzo, V. 2003: Use of differential SAR interferometry in monitoring and modelling large slope instability at Maratea (Basilicata, Italy). Engineering Geology 68, 31-51. https://doi.org/10.1016/S0013-7952(02)00197-7.

Blikra, L.H. \& Christiansen, H.H. 2014: A field-based model of permafrost-controlled rockslide deformation in northern Norway. Geomorphology 208, 34-49.

https://doi.org/10.1016/j.geomorph.2013.11.014.

Blikra, L.H., Henderson, I. \& Nordvik, T. 2009: Faren for fjellskred fra Nordnesfjellet i Lyngenfjorden, Troms. Norges geologiske undersøkelse Report 2009.026 (in Norwegian), 29 pp.

Blikra, L.H., Christiansen, H., Kristensen, L. \& Lovisolo, M. 2015: Characterization, Geometry, Temporal Evolution and Controlling Mechanisms of the Jettan Rock-Slide, Northern Norway. In Lollino, G., Giordan, D., Crosta, G.B., Corominas, J., Azzam, R., Wasowski, J. \& Sciarra, N. (eds.): Engineering Geology for Society and Territory Volume 2, Springer International Publishing, 273-278. https://doi.org/10.1007/978-3-319-09057-3_40.

Braathen, A., Blikra, L.H., Berg, S. \& Karlsen, F. 2004: Rock-slope failures in Norway; type, geometry, deformation mechanisms and stability. Norwegian Journal of Geology 84, 67-87.

Cavalié, O., Doin, M.P., Lasserre, C. \& Briole, P. 2007: Ground motion measurement in the Lake Mead area, Nevada, by differential synthetic aperture radar interferometry time series analysis: Probing the lithosphere rheological structure. Journal of Geophysical Research: Solid Earth 112, 18 pp.

Chaussard, E., Wdowinski, S., Cabral-Cano, E. \& Amelung, F. 2014: Land subsidence in central Mexico detected by ALOS InSAR timeseries. Remote Sensing of Environment 140, 94-106.

https://doi.org/10.1016/j.rse.2013.08.038.
Chen, C.W. \& Zebker, H.A. 2001: Two-dimensional phase unwrapping with statistical models for nonlinear optimization. Proceedings of the Geoscience and Remote Sensing Symposium, 2000 7, 3213-3215.

Elvebakk, H. 2013: Borehullslogging med optisk televiewer, Jettan 1, Nordnesfjellet, Kåfjord kommune, Troms. Norges geologiske undersøkelse Report 2013.020 (in Norwegian), 96 pp.

Elvebakk, H. 2014: Borehullslogging med optisk televiewer, Bh 2 og Bh 3, Jettan, Nordnesfjellet, Kåfjord kommune, Troms. Norges geologiske undersøkelse Report 2014.016 (in Norwegian), 119 pp.

Eriksen, H.Ø. 2013: Slope displacement patterns observed using satellite InSAR data in the Storfjord-Kåfjord-Lyngen region Troms. Master Thesis, UiT - The Arctic University of Norway, Tromsø, Norway, 138 pp.

Eriksen, H.Ø., Lauknes, T.R., Larsen, Y., Corner, G.D., Bergh, S.G., Dehls, J. \& Kierulf, H.P. 2017: Visualizing and interpreting surface displacement patterns on unstable slopes using multi-geometry satellite SAR interferometry (2D InSAR). Remote Sensing of Environment 191, 297-312.

https://doi.org/10.1016/j.rse.2016.12.024.

Fialko, Y., Simons, M. \& Agnew, D. 2001: The complete (3-D) surface displacement field in the epicentral area of the 1999 MW7.1 Hector Mine Earthquake, California, from space geodetic observations. Geophysical Research Letters 28, 3063-3066.

https://doi.org/10.1029/2001GL013174.

Fialko, Y., Sandwell, D., Simons, M. \& Rosen, P. 2005: Threedimensional deformation caused by the Bam, Iran, earthquake and the origin of shallow slip deficit. Nature 435, 295-299.

https://doi.org/10.1038/nature03425.

Ganerød, G.V. 2013: Geological logging of drill core from borehole NN-01-12 at Jettan, Nordnes mountain in Troms county, Northern Norway. Norges geologiske undersøkelse Report 2013.042, 59 pp.

Ganerød, G.V. 2014: Geological logging of drill cores from borehole BH 02-13 and BH 03-13 at Jettan, Nordnes mountain in Troms county, Northern Norway. Norges geologiske undersøkelse Report 2014.005, 64 pp.

Goldstein, R.M. \& Werner, C.L. 1998: Radar interferogram filtering for geophysical applications. Geophysical Research Letters 25, 40354038. https://doi.org/10.1029/1998GL900033.

Goldstein, R.M., Engelhardt, H., Kamb, B. \& Frolich, R.M. 1993: Satellite Radar Interferometry for Monitoring Ice Sheet Motion: Application to an Antarctic Ice Stream. Science 262, 1525-1530. https://doi.org/10.1126/science.262.5139.1525.

Gourmelen, N., Amelung, F., Casu, F., Manzo, M. \& Lanari, R. 2007: Mining-related ground deformation in Crescent Valley, Nevada: Implications for sparse GPS networks. Geophysical Research Letters 34, L09309. https://doi.org/10.1029/2007GL029427.

Henderson, I.H.C., Osmundsen, P.T. \& Redfield, T. 2008: ROS Fjellskred i Troms: Statusrapport 2007. Norges geologiske undersøkelse Report 2008.025 (in Norwegian), 38 pp.

Hernes, I. 2014: Fjellskred ved Indre Nordnes, Nordnesfjellet, Lyngen, Troms - Berggrunnens indre struktur og bevegelsesmekanismer basert på strukturell analyse og overvakingsdata. Master Thesis, UiT - The Arctic University of Norway, Tromsø, Norway (in Norwegian), $136 \mathrm{pp}$.

Husby, E.H. 2011: Fjellskred i Nomedalstinden: En strukturstyrt masseutglidning på et underliggende storskala glideplan. Master Thesis, UiT - The Arctic University of Norway, Tromsø, Norway (in Norwegian), 89 pp. 
Indrevær, K., Bergh, S.G., Koehl, J.B., Hansen, J.A., Schherme, E. \& Ingebrigtsen, A. 2013: Post-Caledonian brittle fault zones on the hyperextended SW Barents Sea margin: New insights into onshore and offshore margin architecture. Norwegian Journal of Geology 93, 167-188.

Kierulf, H.P., Steffen, H., Simpson, M.J.R., Lidberg, M., Wu, P. \& Wang, H. 2014: A GPS velocity field for Fennoscandia and a consistent comparison to glacial isostatic adjustment models. Journal of Geophysical Research: Solid Earth 119, 6613-6629. https://doi.org/10.1002/2013JB010889.

Kristensen, L. \& Blikra, L.H. 2013: Bakkebasert InSAR målinger til kartlegging av bevegelse på Jettan og Indre Nordnes. Åknes/ Tafjord Beredskap IKS rapport 03 (in Norwegian), 15 pp.

Kristensen, L., Kjølås, Å., Bergeng, T., Rivolta, C. \& Blikra, L.H. 2011: Ground based radar measurements at Gamanjunni 3 and Oksfjellet, Troms. Åknes/Tafjord Beredskap IKS rapport 09 (in Norwegian), $10 \mathrm{pp}$.

Larsen, Y., Engen, G., Lauknes, T.R., Malnes, E. \& Høgda, K.A. 2005. A generic differential interferometric SAR processing system, with applications to land subsidence and snow-water equivalent retrieval. Proceedings Fringe 2005 Workshop, ESA ESRIN, 28 November-2 December, Frascati, Rome, Italy.

Lauknes, T.R., Shanker, A.P., Dehls, J.F., Zebker, H.A., Henderson, I.H.C. \& Larsen, Y. 2010: Detailed rockslide mapping in northern Norway with small baseline and persistent scatterer interferometric SAR time series methods. Remote Sensing of Environment 114, 2097-2109. https://doi.org/10.1016/j.rse.2010.04.015.

Massonnet, D., Briole, P. \& Arnaud, A. 1995: Deflation of Mount Etna monitored by spaceborne radar interferometry. Nature 375, 567570. https://doi.org/10.1038/375567a0.

Nagler, T., Rott, H., Hetzenecker, M., Scharrer, K., Magnússon, E., Floricioiu, D. \& Notarnicola, C. 2012: Retrieval of 3D-glacier movement by high resolution X-band SAR data. 2012 IEEE International Geoscience and Remote Sensing Symposium, 32333236. https://doi.org/10.1109/IGARSS.2012.6350735.

Nordvik, T., Blikra, L.H., Nyrnes, E. \& Derron, M.H. 2010: Statistical analysis of seasonal displacements at the Nordnes rockslide, northern Norway. Engineering Geology 114, 228-237.

https://doi.org/10.1016/j.enggeo.2010.04.019.

Nystad, T.M. 2014: Utvikling av geologisk modell og stabilitetsanalyse av den mest aktive delen av det ustabile fjellpartiet Jettan på Nordnesfjellet i Troms. Master Thesis, Department of Geology and Mineral Resources Engineering, Norwegian University of Science and Technology, Trondheim, Norway (in Norwegian), 180 pp.

Peltzer, G., Crampé, F., Hensley, S. \& Rosen, P. 2001: Transient strain accumulation and fault interaction in the Eastern California shear zone. Geology 29, 975-978.

https://doi.org/10.1130/0091-7613(2001)029<0975:TSAAFI>2.0.CO;2.

Pieraccini, M. 2013: Monitoring of Civil Infrastructures by Interferometric Radar: A Review. The Scientific World Journal 2013, 8 pp.

Rasmussen, E. 2011: Fjellskred i Laksvatnfjellet, Balsfjord, Troms: indre struktur, morfologi og skredmekanismer. Master Thesis, UiT - The Arctic University of Norway, Tromsø, Norway (in Norwegian), 142 pp.

Righini, G., Raspini, F., Moretti, S. \& Cigna, F. 2011: Unsustainable use of groundwater resources in agricultural and urban areas: a persistent scatterer study of land subsidence at the basin scale. WIT Transactions on Ecology and the Environment 144, 81-92.

https://doi.org/10.2495/ECO110071.
Rønning, J.S., Dalsegg, E., Heincke, B.H., Juliussen, H. \& Tønnesen, J.F. 2008: Geofysiske målinger på Nordnesfjellet sommeren 2007, Kåfjord kommune, Troms. Norges geologiske undersøkelse Report 2008.024 (in Norwegian), 33 pp.

Skrede, I. 2013: Jettan, Nordnesfjellet, Kåfjord, Troms-indre geomtri og struktur, kinematikk og styrande faktorar av eit ustabilt fjellparti, basert på strukturellanalyse, geomorfologi og overvakingsdata. Master Thesis, UiT - The Arctic University of Norway, Tromsø, Norway (in Norwegian), 176 pp.

Skrede, I. 2015: Radarkampanje ved Nordnesfjellet 2014, Norges vassdrags- og energidirektorat Report 40-2015 (in Norwegian), 22 pp.

Stead, D. \& Eberhardt, E. 2013: Understanding the mechanics of large landslides. Italian Journal of Engineering Geology and Environment Book Series 6, 85-112.

Strozzi, T., Wegmuller, U., Tosi, L., Bitelli, G. \& Spreckels, V. 2001: Land Subsidence Monitoring with Differential SAR Interferometry. Photogrammetric Engineering \& Remote Sensing 67, 1261-1270.

Tarchi, D., Rudolf, H., Luzi, G., Chiarantini, L., Coppo, P. \& Sieber, A.J. 1999: SAR interferometry for structural changes detection: a demonstration test on a dam. Geoscience and Remote Sensing Symposium, 1999. IGARSS ' 99 Proceedings. IEEE 1999 International 3, 1522-1524. https://doi.org/10.1109/IGARSS.1999.772006.

Tarchi, D., Casagli, N., Fanti, R., Leva, D.D., Luzi, G., Pasuto, A., Pieraccini, M. \& Silvano, S. 2003: Landslide monitoring by using ground-based SAR interferometry: an example of application to the Tessina landslide in Italy. Engineering Geology 68, 15-30. https://doi.org/10.1016/S0013-7952(02)00196-5.

Tønnesen, J.F. \& Dalsegg, E. 2006: Geofysiske målinger Nordnesfjellet, Kåfjord kommune. Norges geologiske undersøkelse Report 2004.012 (in Norwegian), 19 pp.

Zwaan, K.B. 1988: Geologisk kart over Norge. Berggrunnskart NORDREISA, scale 1:250,000 (in Norwegian), Norges geologiske undersøkelse. 